\title{
A Systematic Map of Agroforestry Research Focusing on Ecosystem Services in the Asia-Pacific Region
}

\author{
Seongmin Shin ${ }^{1}{ }^{\circledR}$, Khaing Thandar Soe ${ }^{2}$, Haeun Lee ${ }^{1}$, Tae Hoon Kim ${ }^{1}$, Seongeun Lee ${ }^{1}$ and \\ Mi Sun Park 1,3,*iD \\ 1 Graduate School of International Agricultural Technology, Seoul National University, \\ 1447 Pyeongchang-daero, Daehwa, Pyeongchang, Gangwon 25354, Korea; seongmin@snu.ac.kr (S.S.); \\ haeunl630@snu.ac.kr (H.L.); switch-thkim@snu.ac.kr (T.H.K.); lse1229@snu.ac.kr (S.L.) \\ 2 Research Institute of Agriculture and Life Sciences, Seoul National University, 1 Gwanakro, Gwanakgu, \\ Seoul 08826, Korea; khaing9588@snu.ac.kr \\ 3 Center for International Agricultural Development, Institutes of Green Bio Science and Technology, \\ Seoul National University, 1447 Pyeongchang-daero, Daehwa, Pyeongchang, Gangwon 25354, Korea \\ * Correspondence: mpark@snu.ac.kr; Tel.: +82-33-339-5858
}

Received: 20 February 2020; Accepted: 21 March 2020; Published: 26 March 2020

\begin{abstract}
Agroforestry is an intensive land management system that integrates trees into land already used for crop and animal farming. This provides a diverse range of ecosystem services by bridging the gaps between agriculture, forestry, and animal husbandry. It is an important approach to improve the environmental, economic, and social benefits of complex social-ecological systems in the Asia-Pacific region. This paper aims to examine the research trends in agroforestry and the current state of knowledge, as well as the research gaps in the ecosystem services of agroforestry in this region. A systematic mapping methodology was applied, where analysis units were academic articles related to agroforestry practices in the Asia-Pacific region. The articles published between 1970 and 2018 were collected through the international specialized academic database, SCOPUS. They were coded according to the types of agroforestry practices and ecosystem services. The research result indicates silvorable systems, especially plantation crop combinations, tree management, habitats for species, biological controls, and maintenance of genetic diversity and gene-pools, are the most prominent in the agroforestry research from the Asia-Pacific region. Approximately $60 \%$ of all research articles include case studies from India, China, Indonesia, and Australia. Research on agroforestry has changed following the international discourse on climate change and biodiversity. Therefore, this systematic map improves our understanding of the nature, volume, and characteristics of the research on ecosystem services with regard to agroforestry in the Asia-Pacific region. It provides scholars with a springboard for further meta-analysis or research on agroforestry and ecosystem services.
\end{abstract}

Keywords: agroforestry; ecosystem services; Asia-Pacific region; systematic map

\section{Introduction}

Agroforestry is defined as agriculture that incorporates trees [1]. However, this definition is oversimplified. Agroforestry is in fact much more complex. Geographic information system (GIS) data show that $43 \%$ of all agricultural land, globally, is used for agroforestry, which is more than 1 billion hectares [2]. Agroforestry systems in the Asia Pacific region are abundant under various agro-ecological environments, especially in Indonesia, Malaysia, India, Sri Lanka, and Bangladesh, as the practices have played important roles there since ancient times [3]. As agroforestry practices in the region have evolved over a long period of time, they utilize many novel and historic strategies to fulfill the basic needs of the smallholder farmers for food, fodder, medical products, fuelwood, and as 
a cash income [4]. In particular, multifunctional home gardens managed in a traditional way in the Asia-Pacific region are important for enhancing food security [5], diversity, and cultural and ecological functions, by providing natural fertilizer from trees, keeping soil resources, and favoring habitats for improved agrobiodiversity environments, which can mitigate climate change [6,7]. The experiences from these traditional systems highlight the importance of agroforestry in the twenty-first century to tackle land management problems, such as food insecurity, deforestation and forest degradation, biodiversity loss, and climate change.

However, socio-economic and technological factors have led to changes in traditional land use systems over time, in line with the paradigm shifts from traditional cultivation and monocropping to sustainable land use [4,8]. The paradigm shifts resulting from market economies, and specifically, exotic commercial crops have brought about the decline of traditional land-use systems [7,9]. For instance, the historic predominant land-use systems, such as home gardens, have been converted for land-use intensification in Asia [9-11]. As the population pressure and food requirements have driven mono specific production systems [12], agricultural and forest policies also began to favor fast-growing and commercial species, which had adverse impacts on agroforestry in Asia. The industrial agriculture systems have resulted in new social and environmental challenges, by altering the biotic patterns and interactions [13,14].

For this reason, the traditional methods have recently been revisited for their ecosystem services, including contribution to economic, cultural, and social values [11]. Several countries have enacted agroforestry-related policies. The national agricultural policy of India supports farmers adopting agroforestry practices to increase their incomes by providing them with credit and technologies. The national forestry policy of Sri Lanka stresses the important role of agroforestry in offering timber and nontimber forest products (NTFPs), and bio-energy conserving environments at the same time [15]. However, in most countries, public policies have lacked incentives and support to drive uptake of agroforestry systems and do not consider ecosystem services derived from agroforestry as sustainable production methods worth promoting to conserve agrobiodiversity [9,16-19]. The forest policies of Pakistan, for example, mention farm forestry and its importance but offer almost no practical implementations [20]. In this context, stabilizing agroforestry in the Asia-Pacific region should be warranted, owing to the global challenges related to food security [5], biodiversity preservation, climate change, and the great number of stakeholders that rely on agroforestry for their subsistence [11].

International organizations and governments have been investing in agroforestry research and projects in lower-middle-income countries since the 1960s and 1970s [5,21,22], exploring the interactions between agroforestry and ecosystem oriented services in the world, as well as specifically in the Asia-Pacific region [18]. For instance, Chang et al. [19] analyzed bird biodiversity in a coffee agroforestry system in India, Yang et al. [23] described the impact of riparian buffers on biomass in China, and Tiwari et al. [24] calculated the ecosystem services of maize from hillside agroforestry systems in Nepal, but each of these studies focused on only one type of agroforestry. There have been more general studies, such as Bohra et al. [25] who reviewed the socio-economic impacts of agroforestry, Basu [26] who conducted interviews to figure out the impacts of agroforestry on climate change mitigation, and Goswami et al. [27] who explained the estimated biomass and carbon sequestration in diverse agroforestry systems. These studies however, are limited in scope and there is a lack of coherent evidence of their effectiveness. This is partly because it is a complex process to synthesize the regional research and it is difficult to interpret the interrelations of agroforestry and ecosystem services. There are number of reasons for this. First, ecosystem services are interrelated, and multifaceted trade-offs vary depending on the service and spatial scale [28]. Second, the results reporting the benefits [17,29] and disservices $[30,31]$ are inconsistent. Third, agroforestry practices in different disciplines resulted in a lack of synthesis of the evidence.

One of the solutions for synthesizing the information, when there is disparate evidence, is a systematic map, providing a robust method to identify and present research evidence extracted from peer-reviewed papers and grey literature [22,32-34]. The rigorous methodology describes the 
characteristics and trends of research on a broad scale, and, in part, fills the knowledge gaps by bringing together repeatable and quantitative evidence [33,34].

Previous works to synthesize the knowledge of agroforestry and ecosystem services have been conducted in some regions, including Europe [35], high-income countries [22], and low- and middle-income countries [36], but no study has systematically identified and described the nature, volume, and characteristics of the research in the field of agroforestry and ecosystem services in the Asia-Pacific region. To make up for the limits of the systematic maps, several previous papers have reported meta-analysis investigations $[17,31,37]$. This study provides comprehensive and systematic evidence about agroforestry and its impacts on ecosystem services by mapping the results of previously published investigations from around the Asia-Pacific agroforestry region. The systematic map aims to catalog the available knowledge and show the research characteristics and trends from the existing findings in the field, providing the first synthesis of ecosystem services of the Asia-Pacific agroforestry.

The following research questions were addressed:

1. What is the quantitative distribution of evidence-based research regarding agroforestry and ecosystem services in the Asia-Pacific region?

2. What types of agroforestry practices and ecosystems have been studied and how do they change over time?

3. How are research approaches between agroforestry systems and ecosystem services interlinked?

\section{Theoretical Background}

\subsection{Agroforestry}

Agroforestry is generally said to be a 'new term for an old practice', since the name was not recognized in the literature until the mid-1970s, but it has been in practice for a much longer period of time [3]. Agroforestry is a collection of land-use practices, systems, and technologies that integrates woody perennials into crop- and animal-based agricultural practices [38]. The main requirements for agroforestry are that at least two plants or animal species are included in the land-use system and one of these should be a woody perennial. Moreover, there are economic and ecological interactions between two or more production systems, such as tree-crop, tree-livestock, or tree-fish. Compared with intensified agriculture systems, the cycle of agroforestry systems may take one or more years and be more complex structurally, economically, ecologically, and functionally [39].

Agroforestry types consist of agrisilviculture, silvopasture, agrosilvipasture, forest farming, and urban agroforestry, amongst others, including tree integration with fisheries or beekeeping. Agrisilviculture is defined as integrating trees with cropping, also called silvorable, while silvopasture is an integrated system of trees and livestock, and agrosilvipasture is a tree-integrated system with livestock and crops together. Forest farming is an operation that raises livestock or produces crops and NTFPs within forests [38]. Agroforestry systems are classified using different criteria such as the different configuration and structure of the system's components. They are also identified based on the temporal sequences to bring in different species to the systems and the function of trees in agroforestry practices, such as providing shade, breaking wind, or conserving soil. As some agroforestry types are more suitable for certain environmental conditions than other systems, ecological appropriateness and the level or scale of inputs for the systems management for commercial uses can also differ [39]. Table 1 describes and identifies common agroforestry practices. These practices are mutually exclusive. 
Table 1. Major agroforestry practices $[38,40,41]$.






\subsection{Ecosystem Services}

The term 'ecosystem services 'was initially employed by Ehrlich and Mooney [42] to bring attention to the human activities causing land degradation and consequently the diminishing functions and services delivered by ecosystems [42]. With the rising awareness of the importance of ecosystem services and the inseparable relationship between ecosystem services and human activities, research on ecosystem services has been carried out from a multitude of analytical angles [32,43]. Multiple ways to classify ecosystem services exist to assess and reflect the ecosystem [44]. According to the theoretical structure of the Millennium Ecosystem Assessment (MEA) [45], which was created by many experts, ecosystem services contain direct services affecting human provisioning, regulating, and cultural services. Indirect services, such as the supporting services, underpin other services including photosynthesis, nutrient cycling, and primary production [45]. When properly managed, forests and trees provide diverse provisioning services, such as food, timber, raw material, and medical products [46,47]. Other investigations have assessed services forests provide at the local level, including pollination [48,49], biodiversity [9,16-19,50,51], pest control [52,53], moderation of nutrient run-off [54], and soil nutrient enhancement [55]. National and global scale studies explain how forest ecosystem services work and contribute to watershed protection, climate regulation, carbon storage [56], and the challenges in integrating the ecosystem services in decision making and implementation [57]. Ecosystem services are classified by using a spatial and functional scale (See Table 2) based on previously defined references [45,57-59]. This helps in defining local, national, and global ecosystem services that forests and agroforestry systems provide. The classification is considered relevant and important in the context of this systematic review.

Ecosystem services act as a transformative lens, revealing the agricultural systems and driving forces that should be considered when trying to understand the relationship between nature and human development [60-62]. Agroforestry has been recognized as an environmentally friendly and cost-effective land-use system for landscape restoration by reconciling production and environmental conservation/enhancement at the landscape level [17,29]. Given that the integrated agroforestry systems can be more efficient at capturing agricultural resources, including water and solar radiation, agroforestry systems in certain conditions can produce more than monoculture systems $[18,63]$. The combination of production and conservation/enhancement introduced a revitalization of agroforestry.

Each type of agroforestry practice contributes to ecosystem services in a different way. The detailed impacts of agroforestry practices on ecosystem services are listed below by the types of ecosystem services (Table 2). First, well managed agroforestry provides provisioning services; food $[5,17,29,45,64]$, fiber [17], freshwater [18], raw materials [17], fuel wood [29], NTFPs [17,29], medicinal resources [17], genetic resources, and ornamental resources [17]. Second, agroforestry also delivers regulating ecosystem services; erosion control, climate change moderation [29], nutrient retention [17,29], carbon storage and sequestration [17], and pest control [18]. Moreover, agroforestry systems play a critical role in biodiversity enhancement [9,16-19,50,51] and climate regulation [18]. More specifically, soil can be more fertile in agroforestry systems where leguminous trees collect the nitrogen in their leaves and roots and provide it to the crops [18]. Trees planted and interspersed with crops can incorporate their leaves into the soil, which increases yields [18]. In silvopastural systems, animals that inhabit a forest can make the soil rich by providing manure [41]. In this way, the lands can be more productive and give farmers more stable yields, which improves food security [5,45]. Cultural services are a corresponding outcome from agroforestry and include: social relations [3], cultural heritage values [18], ecotourism recreation [16], spiritual values, experience and knowledge systems, and educational values [3]. For example, communities can share the byproducts of agroforestry, such as cultural and household goods and utilities [64]. However, it has also been reported that agroforestry has neutral and negative impacts on ecosystem services [30,31]. 
Table 2. Ecosystem service types and components [45,57-59].

\begin{tabular}{|c|c|c|c|}
\hline Ecosystem Services & Category & Definition & Components \\
\hline \multirow{7}{*}{$\begin{array}{l}\text { Provisioning services } \\
\text { (products obtained } \\
\text { from ecosystems) }\end{array}$} & Food & $\begin{array}{l}\text { Presence of edible plants and } \\
\text { animals }\end{array}$ & $\begin{array}{l}\text { Seafood, gamete, crops, } \\
\text { wild foods, and species }\end{array}$ \\
\hline & Fiber & $\begin{array}{l}\text { Presence of species or abiotic } \\
\text { components with potential use for } \\
\text { timber or textile }\end{array}$ & Timber, cotton, hemp, silk \\
\hline & $\begin{array}{l}\text { Freshwater/ water/ } \\
\text { drinking water/ } \\
\text { irrigation water }\end{array}$ & Presence of water reservoirs & Water \\
\hline & $\begin{array}{l}\text { Raw materials/ } \\
\text { fuel wood/ biofuels/ } \\
\text { bioenergy/energy/ } \\
\text { hydroelectricity/ } \\
\text { biomass/charcoal/ } \\
\text { firewood/NTFPs }\end{array}$ & $\begin{array}{c}\text { Presence of species or abiotic } \\
\text { components with potential use as } \\
\text { a fuel or raw material }\end{array}$ & $\begin{array}{l}\text { Lumber, skins, fuel wood, } \\
\text { organic matter, fodder, and } \\
\text { fertilizer }\end{array}$ \\
\hline & $\begin{array}{l}\text { Biochemicals/ } \\
\text { pharmaceuticals/ } \\
\text { medicinal resources }\end{array}$ & $\begin{array}{l}\text { Presence of species or abiotic } \\
\text { components with potentially } \\
\text { useful chemicals and/or medicinal } \\
\text { uses }\end{array}$ & $\begin{array}{l}\text { Pharmaceuticals, chemical } \\
\text { models, and test and assay } \\
\text { organisms }\end{array}$ \\
\hline & Genetic resources & $\begin{array}{c}\text { Presence of species with } \\
\text { (potentially) useful genetic } \\
\text { material }\end{array}$ & $\begin{array}{l}\text { Crop improvement genes, } \\
\text { and health care }\end{array}$ \\
\hline & Ornamental resources & Presence of species or abiotic & $\begin{array}{c}\text { Fashion, handicrafts, } \\
\text { jewelry, pets, worship, } \\
\text { decoration, and souvenirs }\end{array}$ \\
\hline \multirow{7}{*}{$\begin{array}{l}\text { Regulating and } \\
\text { supporting (benefits } \\
\text { obtained from the } \\
\text { regulation of } \\
\text { ecosystem processes } \\
\text { and underpinning } \\
\text { services that enable } \\
\text { other services to } \\
\text { function) }\end{array}$} & Air quality maintenance & $\begin{array}{l}\text { The capacity of ecosystems to } \\
\text { extract aerosols and chemicals } \\
\text { from the atmosphere }\end{array}$ & $\begin{array}{l}\text { The ability of the } \\
\text { atmosphere to cleanse } \\
\text { itself }\end{array}$ \\
\hline & $\begin{array}{c}\text { Carbon sequestration and } \\
\text { storage }\end{array}$ & $\begin{array}{l}\text { Regulation of the global climate by } \\
\text { storing and sequestering } \\
\text { greenhouse gases. Removing } \\
\text { carbon dioxide from the } \\
\text { atmosphere and locking it away in } \\
\text { their tissues }\end{array}$ & $\begin{array}{l}\text { Net source of carbon } \\
\text { sequestration }\end{array}$ \\
\hline & $\begin{array}{c}\text { Water regulation/ } \\
\text { water flows/ } \\
\text { water purification and } \\
\text { waste treatment/ } \\
\text { waste-water treatment }\end{array}$ & $\begin{array}{l}\text { Role in water infiltration and } \\
\text { gradual release of water, and in } \\
\text { biotic and abiotic processes of } \\
\text { removal or breakdown of organic } \\
\text { matter, xenic nutrients, and } \\
\text { compounds }\end{array}$ & $\begin{array}{l}\text { Chemical condition of } \\
\text { freshwaters and saltwater }\end{array}$ \\
\hline & $\begin{array}{l}\text { Regulation of human } \\
\text { diseases }\end{array}$ & $\begin{array}{l}\text { Control of pest populations } \\
\text { through trophic relations }\end{array}$ & Disease control \\
\hline & Pollination & $\begin{array}{l}\text { Contribute to abundance and } \\
\text { effectiveness of pollinators }\end{array}$ & $\begin{array}{l}\text { Pollination and seed } \\
\text { dispersal }\end{array}$ \\
\hline & $\begin{array}{l}\text { Moderation of extreme } \\
\text { events/ storm protection/ } \\
\text { erosion control/ } \\
\text { climate regulation }\end{array}$ & $\begin{array}{l}\text { Influence on local and global } \\
\text { climate through land-cover and } \\
\text { biologically mediated processes, } \\
\text { and the role of forests in } \\
\text { dampening extreme events }\end{array}$ & $\begin{array}{l}\text { Storm and flood protection, } \\
\text { micro and regional climate } \\
\text { regulation }\end{array}$ \\
\hline & $\begin{array}{c}\text { Soil formation/ } \\
\text { soil composition/ } \\
\text { maintenance of soil } \\
\text { fertility/ } \\
\text { nutrient cycling }\end{array}$ & $\begin{array}{l}\text { Role of natural processes in soil } \\
\text { formation, regeneration, and } \\
\text { composition }\end{array}$ & $\begin{array}{l}\text { Buffering and attenuation } \\
\text { of mass flows }\end{array}$ \\
\hline
\end{tabular}


Table 2. Cont.

\begin{tabular}{|c|c|c|c|}
\hline Ecosystem Services & Category & Definition & Components \\
\hline & Primary production & $\begin{array}{c}\text { The assimilation or accumulation } \\
\text { of energy and nutrients by } \\
\text { organisms }\end{array}$ & $\begin{array}{l}\text { Products supporting } \\
\text { microorganisms, algae, } \\
\text { plants, and animals }\end{array}$ \\
\hline & $\begin{array}{l}\text { Habitats for species/ } \\
\text { biological control/ } \\
\text { maintenance of genetic } \\
\text { diversity/ } \\
\text { gene-pool }\end{array}$ & $\begin{array}{l}\text { Provision of breeding, feeding, or } \\
\text { resting habitat for transient } \\
\text { species/maintenance of a given } \\
\text { ecological balance and } \\
\text { evolutionary processes }\end{array}$ & $\begin{array}{l}\text { Maintenance of nursery } \\
\text { populations and habitats }\end{array}$ \\
\hline \multirow{5}{*}{$\begin{array}{l}\text { Cultural services } \\
\text { (nonmaterial benefits } \\
\text { obtained from } \\
\text { ecosystems that } \\
\text { enrich lives) }\end{array}$} & $\begin{array}{l}\text { Spiritual and religious } \\
\text { values/ } \\
\text { inspiration/spiritual } \\
\text { experience }\end{array}$ & $\begin{array}{c}\text { Landscape features or species } \\
\text { with spiritual and religious } \\
\text { value/landscape features or } \\
\text { species with inspirational value to } \\
\text { human }\end{array}$ & $\begin{array}{l}\text { Use of nature for religious, } \\
\text { heritage, or natural values }\end{array}$ \\
\hline & $\begin{array}{l}\text { Knowledge systems/ } \\
\text { educational values }\end{array}$ & $\begin{array}{c}\text { Features with special educational } \\
\text { and scientific value/interest }\end{array}$ & $\begin{array}{l}\text { Use of natural systems for } \\
\text { school excursions, and } \\
\text { scientific discovery }\end{array}$ \\
\hline & Social relations & $\begin{array}{l}\text { Influence on the types of social } \\
\text { relations that are established in } \\
\text { particular cultures. e.g., difference } \\
\text { between fishing, nomadic herding, } \\
\text { or agricultural societies, in many } \\
\text { respects of their social relations }\end{array}$ & \\
\hline & $\begin{array}{l}\text { Cultural heritage values/ } \\
\text { cultural diversity }\end{array}$ & $\begin{array}{l}\text { Culturally important landscape } \\
\text { features or species }\end{array}$ & $\begin{array}{l}\text { Use of nature as a motif in } \\
\text { books, film, painting, } \\
\text { folklore, national symbols, } \\
\text { architecture, advertising, } \\
\text { etc. }\end{array}$ \\
\hline & $\begin{array}{l}\text { Ecotourism/ } \\
\text { tourism/ } \\
\text { recreation/ } \\
\text { aesthetic values }\end{array}$ & $\begin{array}{l}\text { Aesthetic quality of the landscape, } \\
\text { based on e.g., structural diversity, } \\
\text { "greenness", tranquility }\end{array}$ & $\begin{array}{l}\text { Ecotourism, outdoor } \\
\text { sports, and recreation }\end{array}$ \\
\hline
\end{tabular}

\section{Materials and Methods}

Evidence-based methods, including systematic reviews, were developed to support policy decision making by providing scientific information [65]. The methods are now employed in a diverse array of fields, such as conservation and environmental management [66,67]. The methods have advantages such as transparency, robustness, independence, and comprehensiveness and help to develop a comprehensive picture and new knowledge, by analyzing previous rigorous studies [34,68]. As one of the evidence-based methods, systematic review, which focuses on providing science-based knowledge through existing evidence, was applied to this study on agroforestry and ecosystem services in the Asia-Pacific region. The PRISMA (preferred reporting items for systematic reviews and meta-analyses) flow diagram was adapted from Moher et al. [69] by following four steps: identification, screening, eligibility, and inclusion. The details are explained in the following sections and Figure 1. 


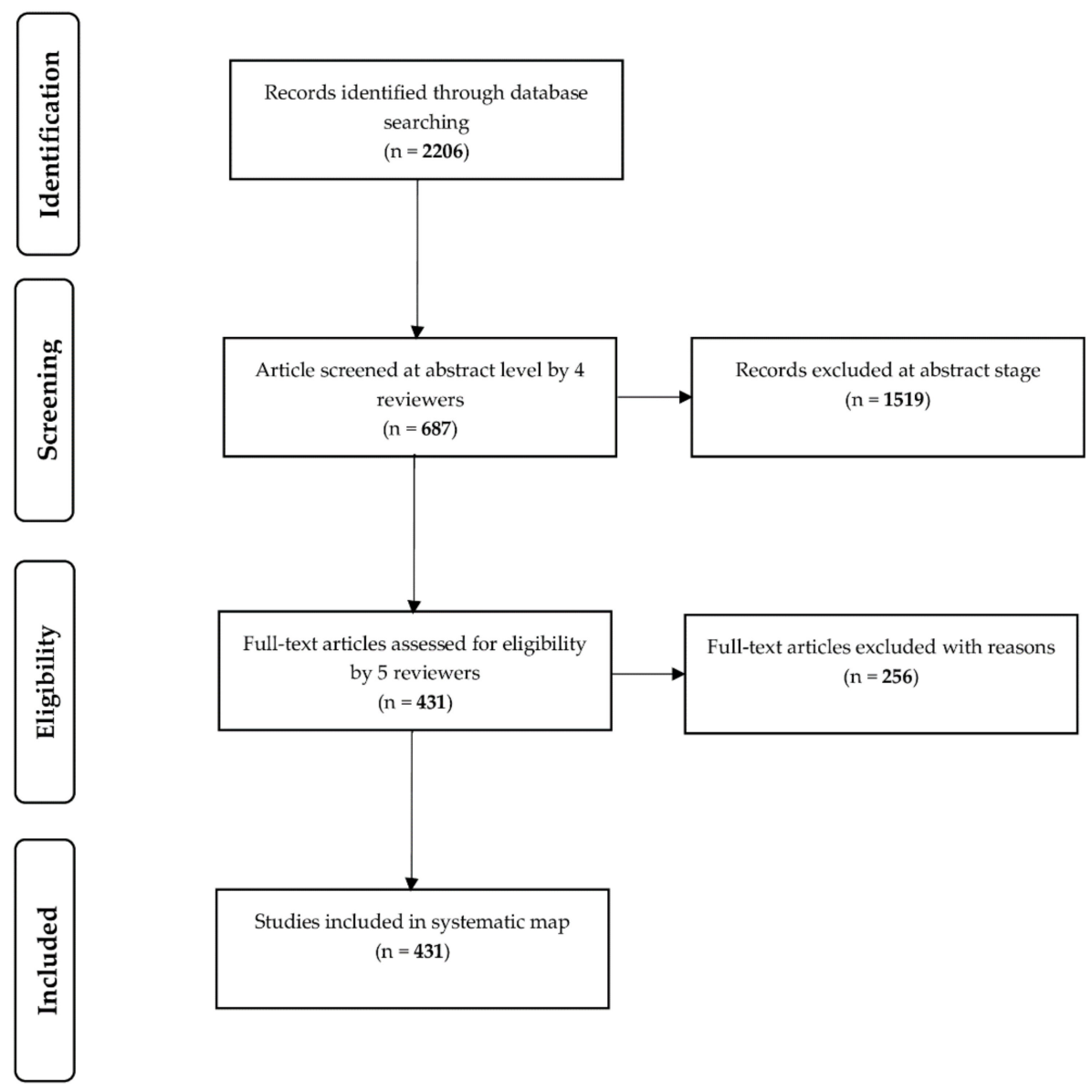

Figure 1. Systematic mapping process of the study, illustrating articles from the initial search to screening for synthesis (identification, screening, eligibility, and inclusion). Articles were found through database search at the identification stage. Then the articles captured were screened based on the categories of agroforestry practices, ecosystem services, and the Asia-Pacific region (through titles, keywords, abstracts, and full text articles) at the screening and eligibility stages. Finally, the articles satisfied with the eligibility criteria were included for the study.

\subsection{Data Collection (Identification)}

The literature search was conducted in English, in February 2019, in a bibliographic database, SCOPUS, which is one of the largest citation databases comprising peer-reviewed articles in life, social, physical, and health science fields, but it does not include grey literature. Search fields included article title, abstract, and keywords. The search strings were a combination of three major topics: agroforestry practices, ecosystem services, and the Asia-Pacific countries and regions (Table A1 of Appendix A). We included single ecosystem services (e.g., irrigation water, hydroelectricity, and nutrient cycling) in the search words to get a wide-range of results using methods mentioned above [57-59,64]. Despite efforts to cover a broad range of terms representing the Asia-Pacific agroforestry practices and their ecosystem services, it is possible that some articles were not captured. All of the extracted articles were stored and shared in a Mendeley database and duplicates were removed.

\subsection{Article Screening, Study Eligibility Criteria and Inclusion}

A total of 2206 articles resulted from the literature search were manually screened in April 2019 through two stages, according to the procedure of the systematic review [65]. The criteria were adjusted for intercoder reliability, and the screening criteria were different at each stage. At the first screening stage, three researchers examined the titles, keywords, and abstracts of the literature to 
check correspondence with the criteria; covering at least one agroforestry practice and assessing the impacts of agroforestry on the ecosystem services. The intercoder agreement was tested using Fleiss' Kappa statistical measure. The eligible articles were included in the study and the others were recorded and excluded. Uncertain articles regarding eligibility were kept for a full text assessment. At the second stage, all included articles were reviewed by five coders who were trained, and the intercoder agreement was measured by the percent agreement method using approximately $10 \%$ of included articles. Through the second stage of full text review, data was coded, and noneligible articles were excluded.

\subsection{Data Coding Strategy}

To categorize the context of the agroforestry practices and ecosystem services in the selected articles, each study was classified according to the study country and types of agroforestry practices and ecosystem services. To categorize the agroforestry practices, a coding category system was developed from previous categorizations (Table 3). The categories of the agroforestry practices included traditional and modern systems modified by the authors. For the ecosystem services, each individual study was coded according to the type of ecosystem service, including provisional, regulating and supporting, and cultural services, according to the Millennium Ecosystem Assessment and previous literature $[45,57]$ (Table 3 ).

Table 3. Coding category system $[38,40,41,45,57-59]$.

\begin{tabular}{|c|c|c|}
\hline \multicolumn{2}{|c|}{ Category } & Sub-Category \\
\hline \multicolumn{2}{|c|}{ Published date } & Year/Month/Day \\
\hline \multicolumn{2}{|c|}{ The study target country } & Name of country \\
\hline \multirow{3}{*}{ Agroforestry } & Silvorable & $\begin{array}{c}\text { Improved or rotational fallow (IR), taungya (TA), forest farming (FF), } \\
\text { alley-cropping (AC), multistory agroforestry (MA), multipurpose } \\
\text { trees (MT), plantation crop combinations and tree management (PC), } \\
\text { home garden (HG), shelterbelts and windbreak/hedgerows/live } \\
\text { hedges (SW), and fuelwood production (FP) }\end{array}$ \\
\hline & Silvopasture & $\begin{array}{l}\text { Trees on rangeland or pastures }(\mathrm{TR}) \text {, protein banks }(\mathrm{PB}) \text {, and } \\
\text { plantation crops with pasture and animals }(\mathrm{PP})\end{array}$ \\
\hline & Agrosilvopasture & $\begin{array}{c}\text { Apiculture with trees (entomoforestry) (AF), } \\
\text { aquaforestry/silvofishery (AS), home gardens involving animals } \\
\text { (HA), multipurpose woody hedgerows (HW), and riparian buffer } \\
\text { strips (RB) }\end{array}$ \\
\hline \multirow{3}{*}{ Ecosystem services } & Provisioning & $\begin{array}{l}\text { Food (FO), fiber (FI), fresh water/ water/ drinking water/ irrigation } \\
\text { water (FW), raw materials/ fuel wood/ biofuels/ bioenergy/ energy/ } \\
\text { hydroelectricity/ biomass/ charcoal/ firewood/ NTFPs (RM), } \\
\text { biochemicals/ pharmaceuticals/ medicinal resources (BC), genetic } \\
\text { resources (GR), ornamental resources (OR), and other (PO) }\end{array}$ \\
\hline & $\begin{array}{l}\text { Regulating/ } \\
\text { supporting }\end{array}$ & $\begin{array}{c}\text { Air quality maintenance (AQ), carbon sequestration and storage } \\
\text { (CS), water regulation/ water flows/ water purification and waste } \\
\text { treatment/ waste-water treatment (CR), regulation of human } \\
\text { diseases (RH), pollination (PL), moderation of extreme events/ } \\
\text { storm protection/ erosion control/ climate regulation (EE), soil } \\
\text { formation/ soil composition/ maintenance of soil fertility/ nutrient } \\
\text { cycling (SF), primary production (PR), habitats for species/biological } \\
\text { control/maintenance of genetic diversity/ gene-pool (HS), and } \\
\text { other (RS) }\end{array}$ \\
\hline & Cultural & $\begin{array}{l}\text { Spiritual and religious values/ inspiration/ spiritual experience (SR), } \\
\text { knowledge systems/ educational values (KS), social relations (SO), } \\
\text { cultural heritage values/ cultural diversity (CH), ecotourism/ } \\
\text { tourism/ recreation/ aesthetic values (ET), and other (CO) }\end{array}$ \\
\hline
\end{tabular}

There was no quality appraisal of the individual articles in the review, because of the large scope and size encompassed by the literature involved. Analysis on the distribution of the evidence base with linkages between the agroforestry practices and ecosystem services was carried out. 
Lastly, a systematic map was created indicating evidence distribution and linkages between agroforestry practices and ecosystem services. Rows represent individual agroforestry practices, and columns are divided into categories of ecosystem services. If the article covered more than one practice or service, then multiple practices or services from one article were mapped.

\section{Results}

\subsection{Number of Articles}

This research follows the systematic mapping process, the PRISMA (preferred reporting items for systematic reviews and meta-analyses) flow diagram adapted from Moher et al. [69] (Figure 1). It illustrated articles from the initial search to screening for synthesis (identification, screening, eligibility, and inclusion). The articles identified through database searching were recorded at the 'identification' stage. Then, the articles captured were screened based on our included agroforestry practices, ecosystem services, and Asia-Pacific region (through title, keywords, abstract, and full text article) during 'screening and eligibility' stages. After full text articles were assessed, the articles with the eligibility criteria were included for the study. The 2206 articles from the SCOPUS database were extracted with the search strings for the agroforestry practices, ecosystem services, and Asia-Pacific countries (Table A1 of Appendix A) [69]. However, a large portion of the selected article were excluded due to irrelevance after checking the titles, keywords, and abstracts (Figure 1). Five reviewers screened the full-text of 687 articles and reduced the number of articles to 431 by excluding the inappropriate studies, such as articles in which the abstracts were written in English, but the main text was in another language. Ultimately, our final map comprised 431 articles. There was a $92.2 \%$ intercoder agreement for the sampled articles selected in the full-screening testing.

There were a few agroforestry-related articles that were published before 1990 and the publication numbers began to rise after this point (Figure 2). Among the selected articles, the articles on the silvorable type of agroforestry practices and the regulating and supporting service type of ecosystem services were dominant.

Figure 3 displays the geographical distribution of the included literature in the systematic review. There were many studies focused on South Asia, Oceania, and North-east Asia, and fewer studies on Western Asia, when compared. At the country level, there were four countries that were dominant, accounting for approximately $60 \%$ of all research articles included in the map: India $(n=122)$, China $(n=70)$, Indonesia $(n=54)$, and Australia $(n=35)$.

(A) Number of articles according to agroforestry practices

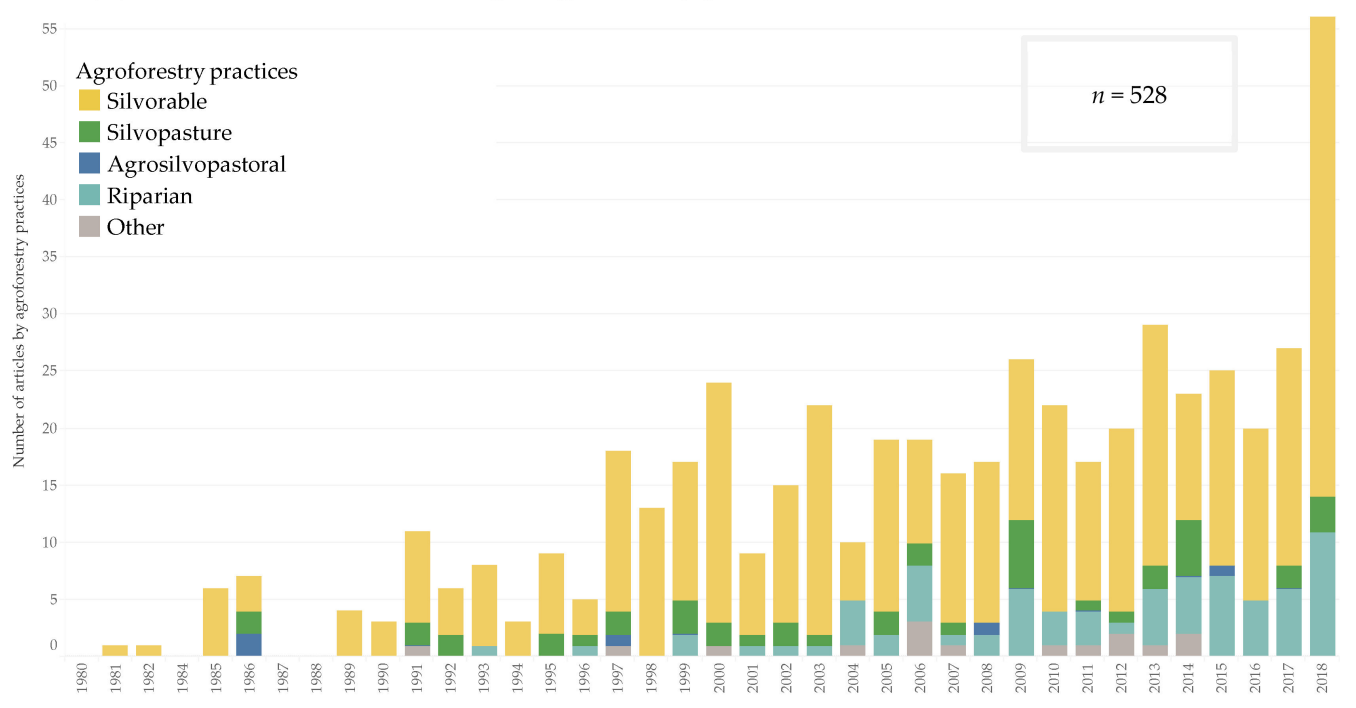

Figure 2. Cont. 
(B) Number of articles according to ecosystem services

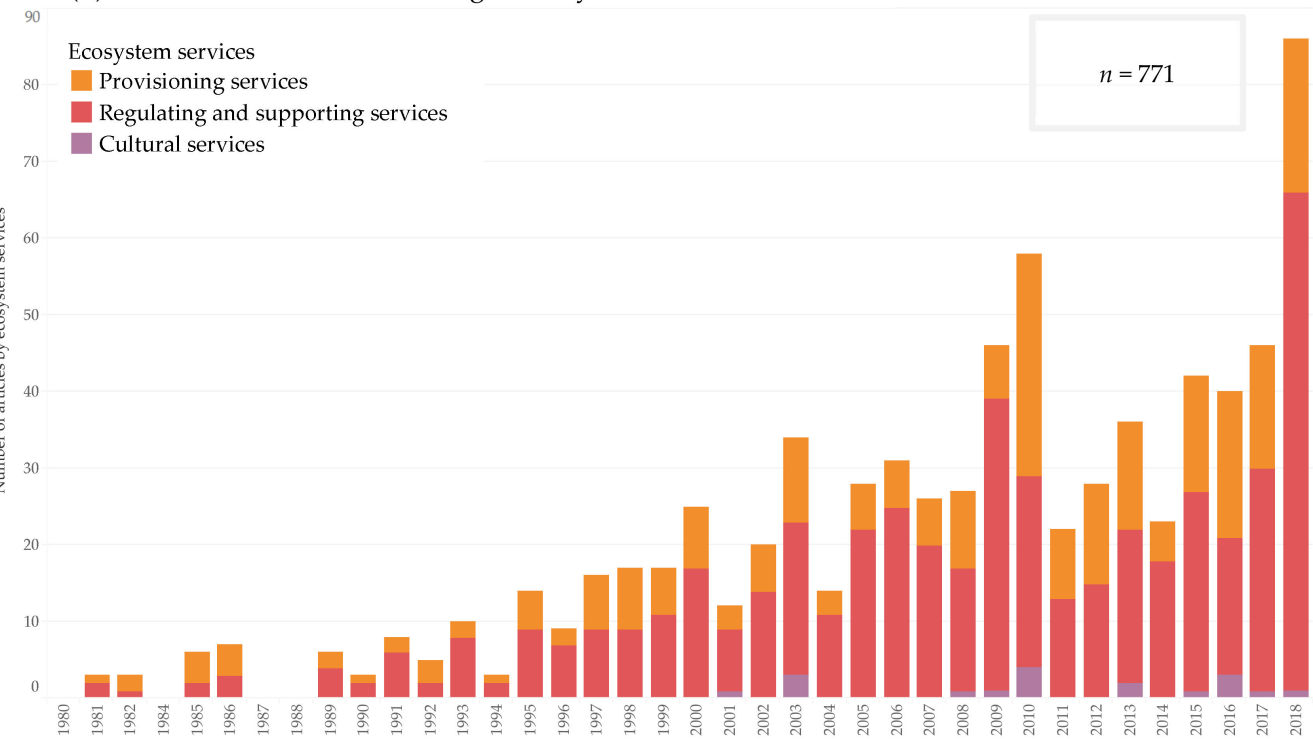

Figure 2. Distribution of the published articles on agroforestry practices and ecosystem services. (A) shows the number of publications related to agroforestry practices by year and (B) shows the number of articles related to ecosystem services by year.

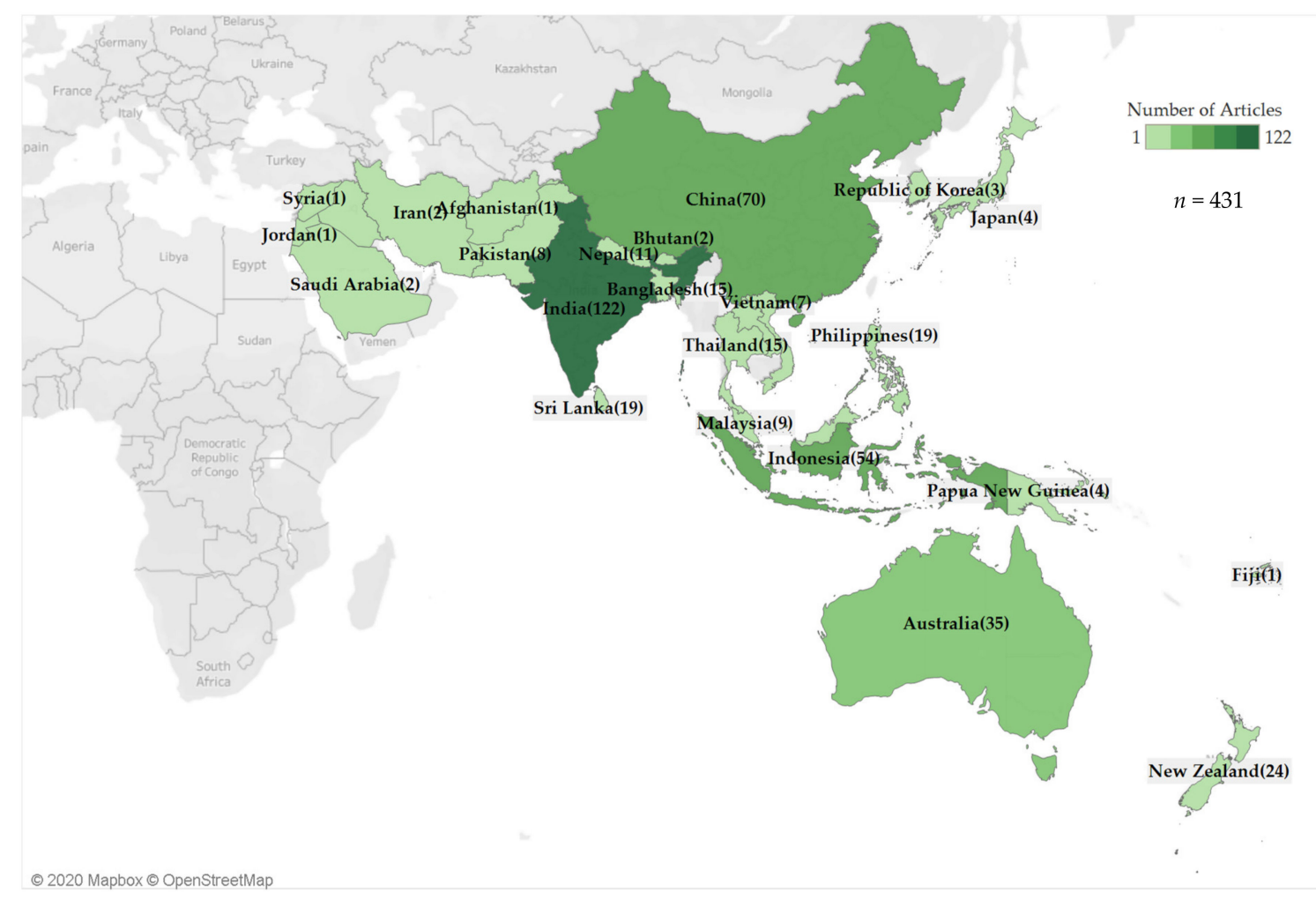

Figure 3. Geographic distribution of the selected articles on agroforestry practices and ecosystem services. Note: The darker the color of the green, the higher the number of the articles focusing on agroforestry practices and ecosystem services in the Asia-Pacific region.

\subsection{Characteristics of Agroforestry Practices and Ecosystem Services}

We classified the practices and services of the articles into multiple subcategories, as agroforestry practices and ecosystem services can be complex. The results show that most of the investigations 
focused on agroforestry practices categorized as silvorable systems/ agrosilviculture, as constituted about $73 \%$ of all the articles. Articles about riparian buffers and the silvopasture practices were the second largest portion of all the studies, making up $12 \%$, and agrosilvopastoral practices were $1.5 \%$ of the investigations. The most studied practices among the individual agroforestry practices were as follows: plantation crop combinations and tree management $(\mathrm{PC}, n=246)$, riparian buffer strips (RB, $n=146)$, home garden (HG, $n=116)$, shelterbelts and windbreak/hedgerows/live hedges (SW, $n=104)$, and alley-cropping (AC, $n=82$ ) (Figure 4).

Overall, most of the articles examined the impacts of agroforestry on regulating and supporting services $(64.5 \%)$, with the majority focusing on soil formation/soil composition/maintenance of soil fertility/nutrient cycling (SF, $n=349$ ), and habitats for species/biological control/maintenance of genetic diversity/gene-pool (HS, $n=226$ ). Less than $3 \%$ of the articles disaggregated the cultural services $(n=36)$.
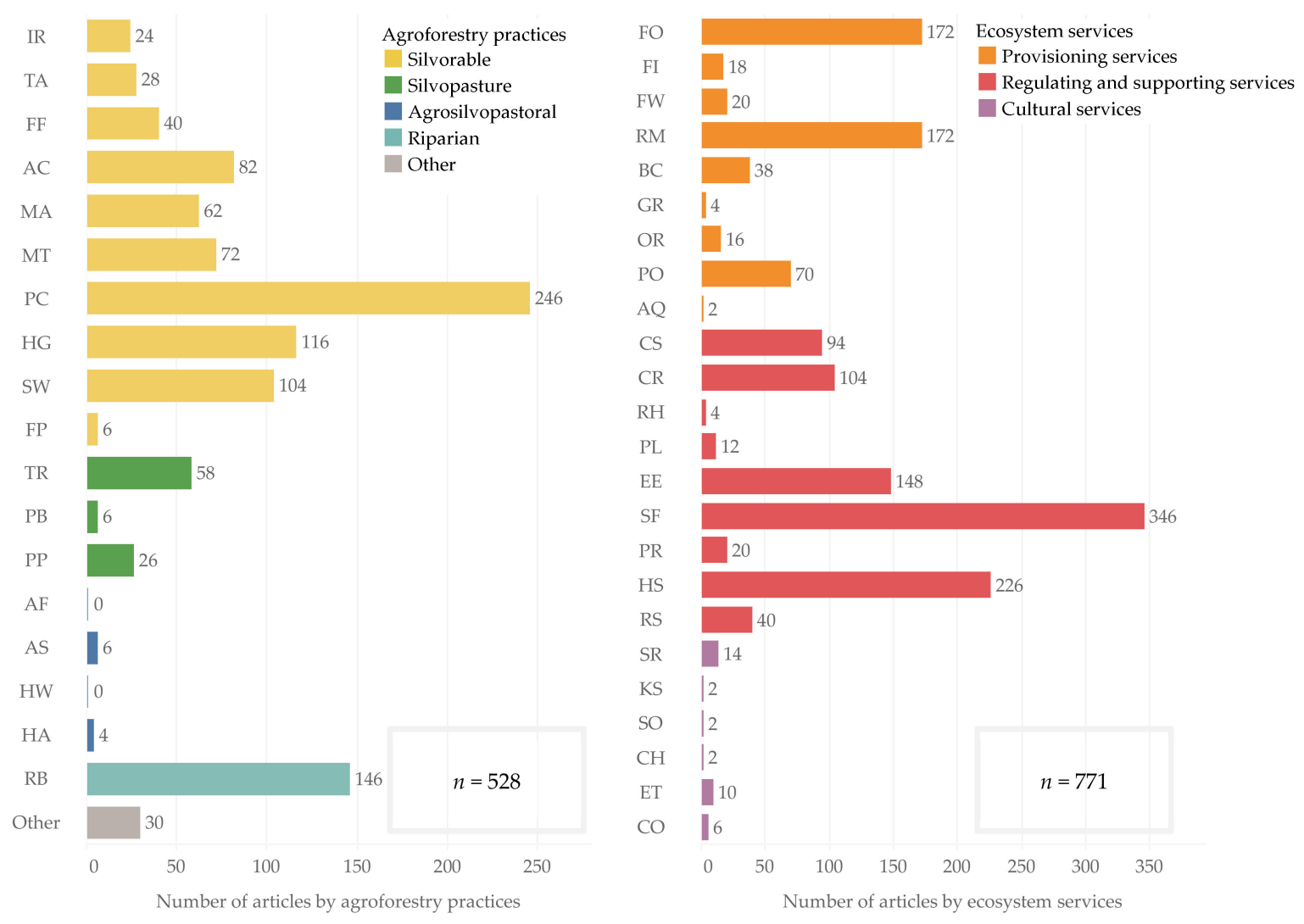

Figure 4. The number of articles by agroforestry practices and ecosystem services.

\subsection{Research Trends for Agroforestry and Ecosystem Services by Decade}

The results showed the research trends for agroforestry and ecosystem services by decade (Figure 5). In the 1980s, the studies on home gardens (HG, $21 \%$ ) and taungya (TA, 16 \%) for silvorable practices were prominent. Shelterbelts and windbreak/hedgerows/live hedges (SW), alley-cropping (AC), and home garden (HG) as silvorable practices were mostly studied in the 1990s. After the 2000s, the publications on riparian buffers (RB) increased, and the plantation crop combinations and tree management (PC) were dominant.

The results of analysis of the ecosystem services in the 1980s showed that it was the provisioning services that were mainly addressed in the agroforestry research, followed by the regulating and supporting services. Soil formation/soil composition/maintenance of soil fertility/nutrient cycling (SF, $28 \%$ ), food (FO, 25\%), and raw materials/ fuel wood/ biofuels/ bioenergy/ energy/ hydroelectricity/ biomass/ charcoal/ firewood/ NTFPs (RM, 25\%) were mainly addressed. In the 1990s and 2000s, 
the focus was on soil formation/ soil composition/ maintenance of soil fertility/ nutrient cycling (SF) and the moderation of extreme events/ storm protection/ erosion control/ climate regulation (EE). During 2010-2018, the majority of the studies focused on habitats for species/ biological control/ maintenance of genetic diversity/ gene-pool (HS) and soil formation/ soil composition/ maintenance of soil fertility /nutrient cycling (SF), and a few studies focused on cultural services, such as spiritual and religious values/ inspiration/ spiritual experience (SR), and ecotourism/ tourism/ recreation/ aesthetic values (ET).

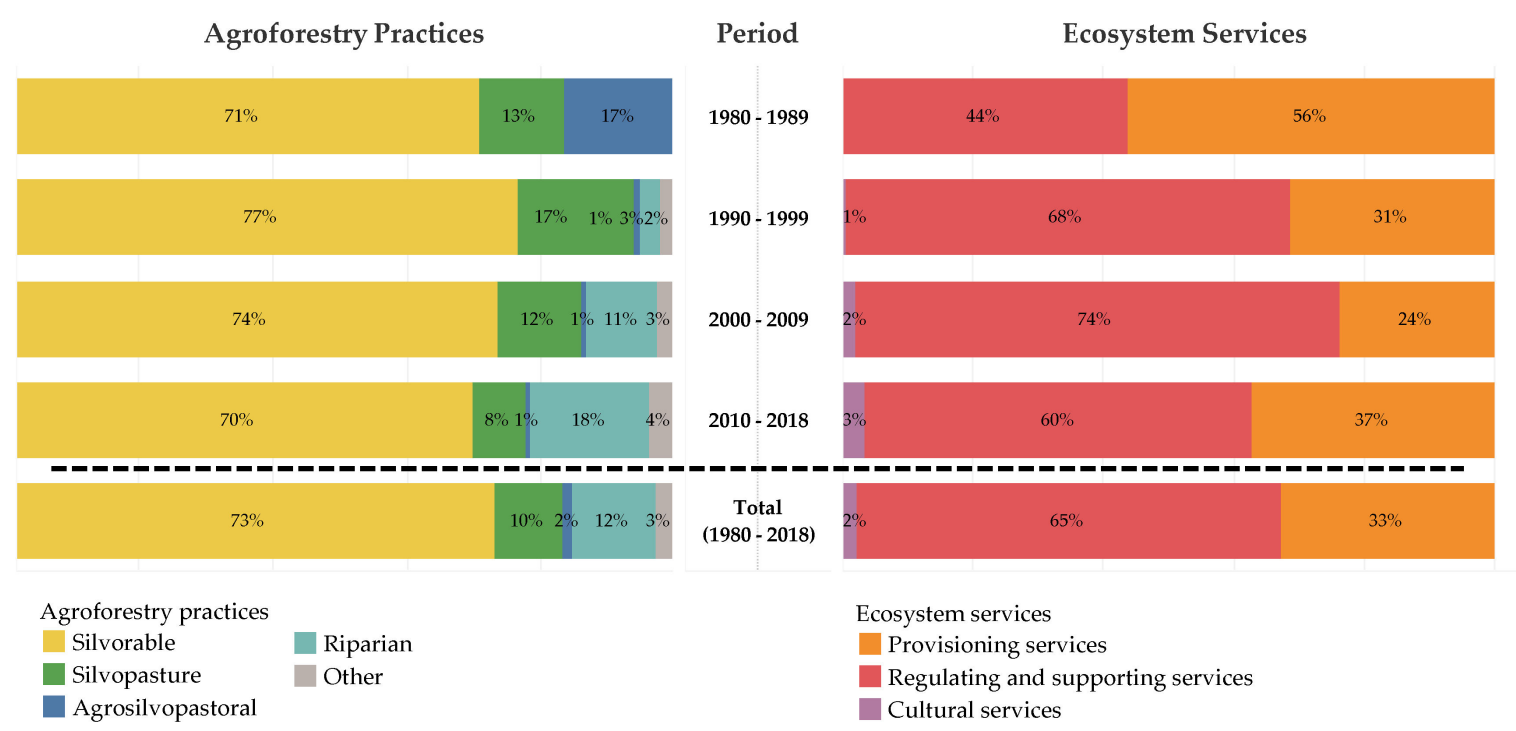

Figure 5. Ratio of the articles on agroforestry practices and ecosystem services by decade.

\subsection{The intersection of Agroforestry Practices and Ecosystem Services}

The linkage between the agroforestry and ecosystem services in the selected articles (Figure 6) was analyzed. The number of articles that included specific types of agroforestry practices and simultaneously specific types of ecosystem services, was calculated. Plantation crop combinations and tree management (PC) and their links to soil formation/soil composition/maintenance of soil fertility/nutrient cycling (SF) and habitats for species/biological control/maintenance of genetic diversity/gene-pool (HS) were most commonly studied in these investigations. Most of the links are between silvorable practices and their relationship to regulating and supporting services. Other pathways were less studied, especially in relation to cultural services. For example, there is no article in the linkage between agrosilvopasture practices and social services. One of the most studied agroforestry practices, home garden (HG), was highly linked to food (FO) and raw materials/ fuelwood/ biofuels/ bioenergy/ energy/ hydroelectricity/ biomass/ charcoal/ firewood/ NTFPs (RM), which are providing services. Unlike home garden (HG), riparian buffer (RB) has a strong connection to regulating and supporting services, including soil formation/ soil composition/ maintenance of soil fertility/ nutrient cycling (SF) and habitats for species/ biological control/ maintenance of genetic diversity/ gene-pool (HS). 


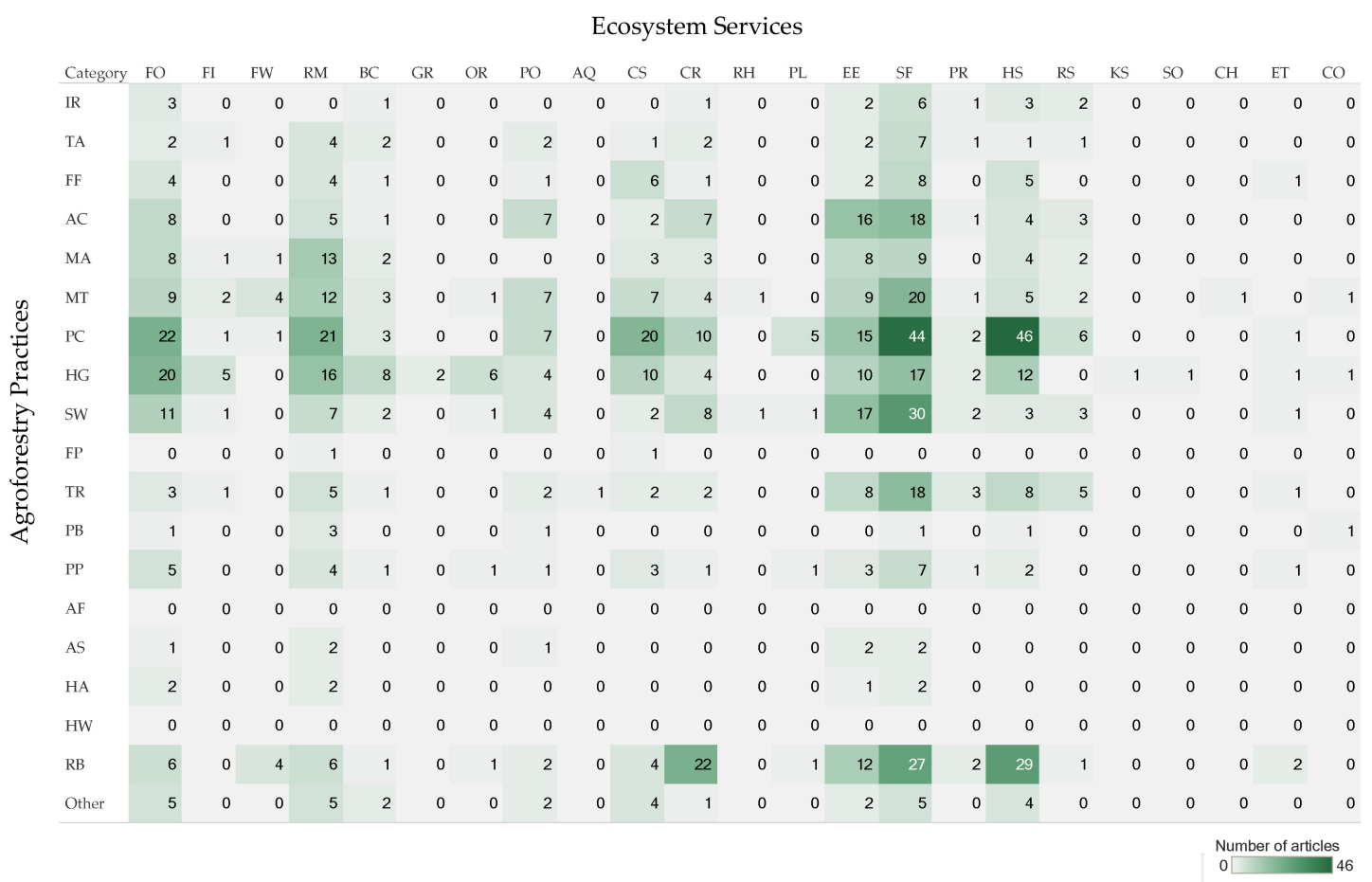

Figure 6. The linkage between agroforestry practices and ecosystem services. Note: The darker the color of the cells, the higher the frequency of articles.

\section{Discussion}

This systematic map was designed to synthesize the knowledge on agroforestry and ecosystem services in the Asia-Pacific region. The results highlight the gaps and limitations of previous agroforestry research works, concentrating on specific practices and ecosystem services and geographic areas. In particular, there were several gaps where there were only a few or no evidence that existed between all types of the agroforestry practices and their impacts on social services. In the following sections, we will explore these gaps and limitations.

\subsection{Geographical Gaps}

The previous research was skewed towards several countries. India was the country with the most research, and this probably reflects a research boom in line with the agroforestry project, including the All India Coordinated Research Project on Agroforestry (ACRPA) in 1983 and policy implementations promoting agroforestry practices $[4,15]$. As India has a long history of agroforestry since the Mesolithic period (8000-2000 BC), agroforestry systems, especially home gardens (HG), have been predominant there over time. Likewise, in this study, home garden (HG) related papers were centered on India, with a high focus on food (FO), raw materials/ fuel wood/ biofuels/ bioenergy/ energy/ hydroelectricity/ biomass/ charcoal/ firewood/ NTFPs (RM), habitats for species/ biological control/ maintenance of genetic diversity/ gene-pool (HS), and soil formation/ soil composition/maintenance of soil fertility/ nutrient cycling (SF). Case studies in China were intensively conducted, with the focus on the riparian buffer (RB), including design of RB and site-specific nutrient management (SSNM) [70]. Western Asian countries however, were rarely studied, and only 0-3 articles were found per country. This asymmetry creates an evidence gap across this geographical area. The gap indicates the limitations of the contextual diversity, as well as the limitations of the applications of research insights to decisions or practices [71]. In this regard, it is highly recommended that the scope of agroforestry research be broadened, to build the geographical evidence base. 


\subsection{Practice and Services Gap}

The research efforts were vastly weighted towards measuring the impacts of silvorable practices on regulating and supporting services, with an emphasis on soil formation/ soil composition/maintenance of soil fertility/ nutrient cycling (SF) and habitats for species/ biological control/ maintenance of genetic diversity/ gene-pool (HS), obtained from plantation crop combinations and tree management (PC) (Figure 4). In addition, the hit maps (Figures 6-9) reveal an extreme emphasis on several practices and services. We can easily find areas with less evidence from studies about agrosilvopastoral practices and cultural services (Figure 6). We set forth two possible reasons for the concentrations in the works. First, that plantation crop combinations and tree management (PC)-related crops, such as rubber and coffee, have been widely cultivated in the Asia-Pacific regions. This is because the top six producers of natural rubber in the world are all in Asia and most Southeast Asian countries cultivate coffee, which likely leads to active studies on the topic. In Europe, silvopastoral systems are well-explored rather than silvorable practices, which are dominant in the Asia-Pacific region, as these systems have traditionally been formed in European landscapes [35]. Second, there were fewer articles measuring social services than articles measuring the regulating and supporting services. The articles about agroforestry practices and cultural services were published later than the articles about other ecosystem services. It was assumed that the term ecosystem services was rarely interpreted in the field of social science. Social services like aesthetic and cultural values should be measured based on a deep understanding of social and cultural contexts. For comprehensive designs of future agroforestry practices, the lack of evidence regarding social services should be addressed and supplemented.

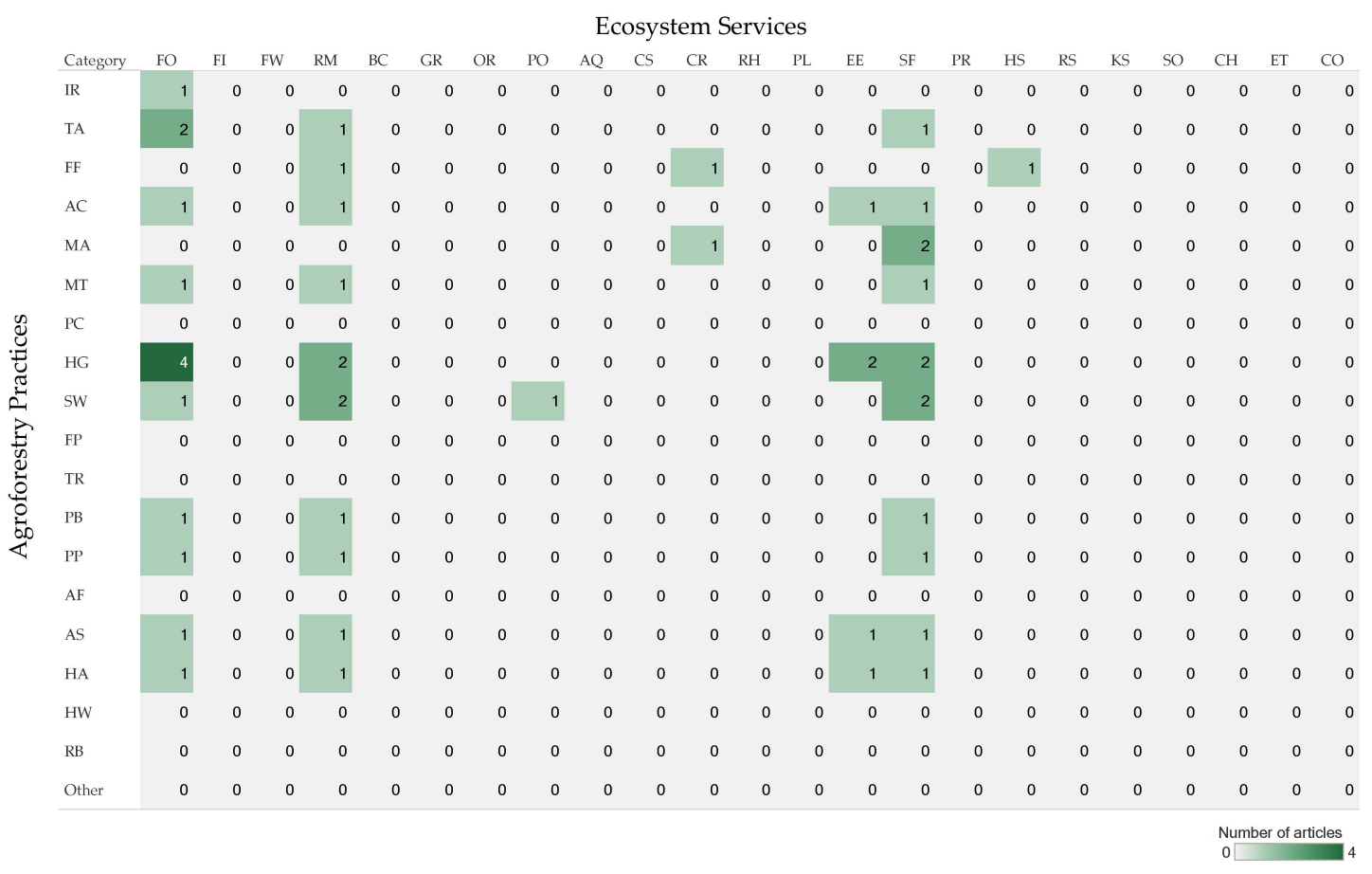

Figure 7. The linkage between agroforestry practices and ecosystem services in the 1980s. Note: The darker the color of the cells, the higher the frequency of articles. 


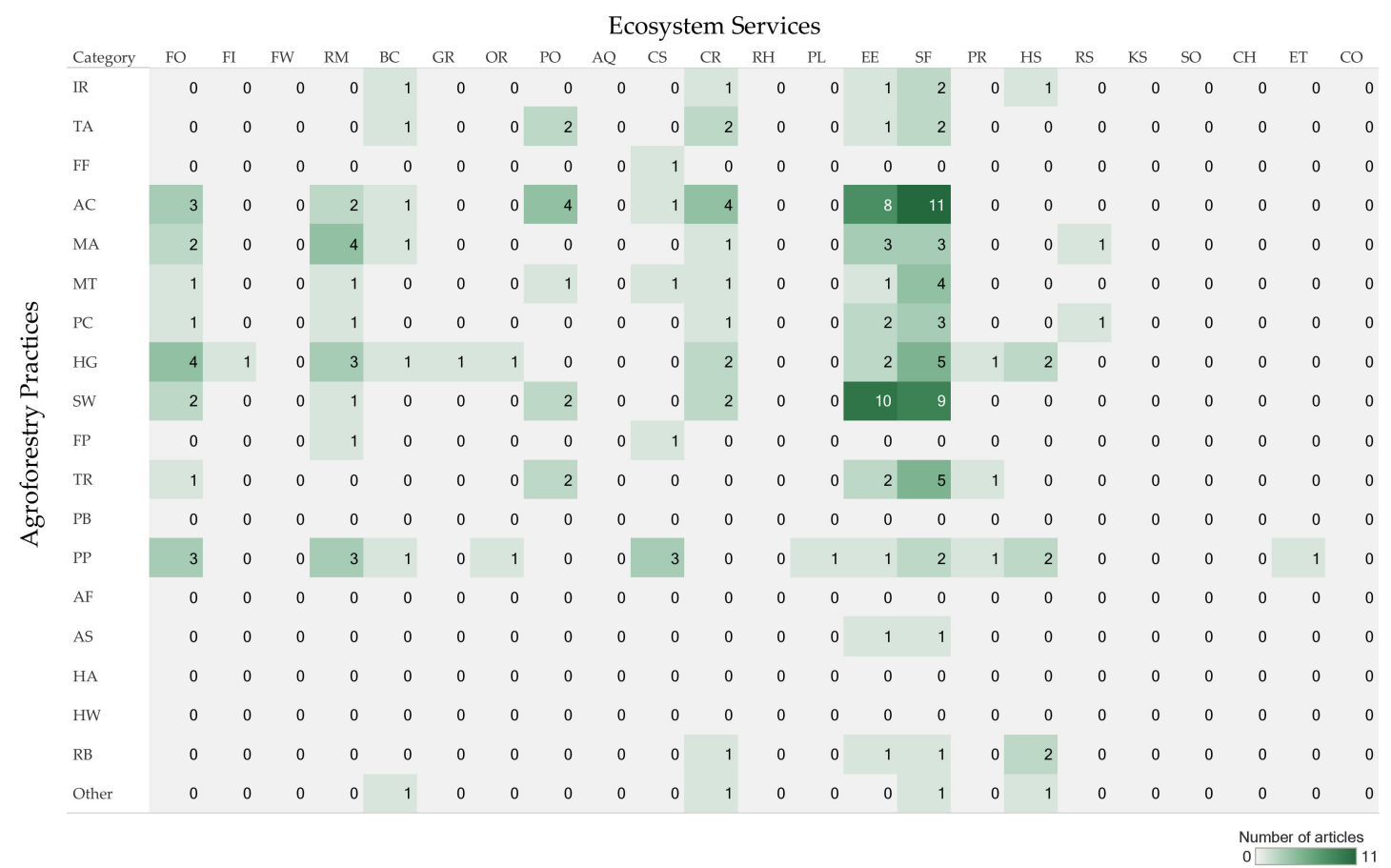

Figure 8. The linkage between agroforestry practices and ecosystem services in the 1990s. Note: The darker the color of the cells, the higher the frequency of articles.

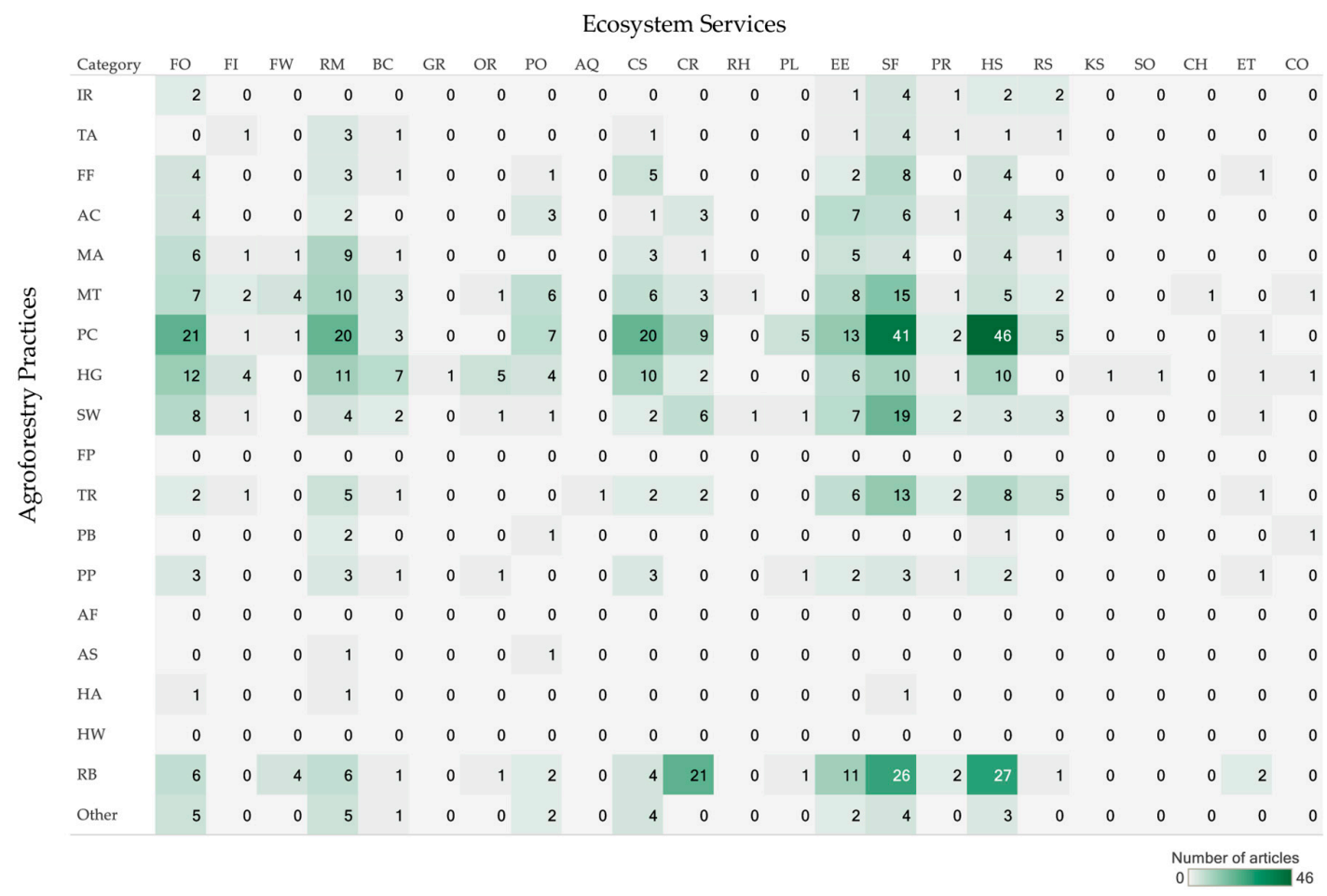

Figure 9. The linkage between agroforestry practices and ecosystem services after 2000. Note: The darker the color of the cells, the higher the frequency of articles.

\subsection{Changing Trends}

Figure 5 confirms the changes in the research trends over time. Although the plantation crop combinations and tree management (PC) have been constantly dealt with as a key topic, the focus has changed with the decades. For more inclusive considerations, we applied a conceptual framework, 
international forest discourses, to help understand research trend changes [72] (Table 4). First, according to Arts et al. (2010), in the 1970s, the Asian countries prioritized economic growth over poverty, and in the 1980s, they valued forests for timber to reduce poverty and create revenues, which are related to the provisioning services, including raw materials/ fuel wood/ biofuels/ bioenergy/ energy/ charcoal/ firewood. In the same way, the systematic map shows that in the 1980s, home gardens (HG) and services including food (FO) and raw materials/ fuel wood/ biofuels/ bioenergy/ energy/ hydro-electricity/ biomass/ charcoal/ firewood/ NTFPs (RM) were the primary topics to study (Figure 7). This indicates that researchers were mainly interested in provisioning the services of agroforestry in the Asia-Pacific region. In the 1990s, there was a shift in valuing ecosystem services. At a global level, policy discourses on climate change emerged in the 1990s and have been prevalent since signing the United Nations Framework Convention on Climate Change (UNFCCC) in 1992. These results also demonstrate the same trend of science discourse on agroforestry in the Asia-Pacific Region. The articles on the moderation of extreme events/ storm protection/ erosion control/ climate regulation (EE), which is interrelated with the discourse on climate change, increased since the 1990s (Figure 8). The discourse on biodiversity became animated later than climate change in the world and in Asia. In more detail, anthropologists started mentioning biodiversity and its benefits and traditional forestry systems like agroforestry came into the spotlight [72]. Globally, since the United Nations Conference on Environment and Development (UNCED) in 1992, forest biodiversity became of higher value and was considered social justice [73]. A multilateral treaty, Convention on Biological Diversity (CBD), has been signed by many countries, including numerous Asian countries. The policy discourse on biodiversity influenced the research on agroforestry in the Asia-Pacific region. Investigations into agroforestry and biodiversity, including habitats for species/ biological control/ maintenance of genetic diversity/ gene-pool (HS), have been numerous since 2000, but prior to this, there were only a few studies that focused on this. Based on these results, it was concluded that science discourses on agroforestry in Asia have been changed following the international discourses on forest policy. Policy and science discourses are inter-related in the field of agroforestry.

Table 4. The change of forest policy discourse and science discourse on agroforestry practices and ecosystem services in the Asia-Pacific region [72].

\begin{tabular}{|c|c|c|c|}
\hline \multirow{2}{*}{ Decade } & \multirow{2}{*}{ Policy Discourse } & \multicolumn{2}{|c|}{ Science Discourse } \\
\hline & & Agroforestry Practice & Ecosystem Services \\
\hline $1980 \mathrm{~s}$ & $\begin{array}{l}\text { Poverty and } \\
\text { economic growth }\end{array}$ & Home garden (HG) & $\begin{array}{c}\text { Food }(\mathrm{FO}), \\
\text { Raw materials (RM) }\end{array}$ \\
\hline $1990 \mathrm{~s}$ & Climate change & $\begin{array}{c}\text { Alley-cropping (AC), } \\
\text { Shelterbelts and windbreak (SW) }\end{array}$ & $\begin{array}{c}\text { Erosion control/ } \\
\text { Climate regulation (EE) }\end{array}$ \\
\hline $2000 s$ & Biodiversity & Riparian buffer strips (RB) & Habitats for species (HS) \\
\hline
\end{tabular}

\subsection{Limitations of the Map}

Though the systematic map was designed to be as robust as possible, by attempting to capture the relevant articles, it was not perfectly inclusive, because of the limited resources and time. We acknowledge the possibility of missed or biased evidence for several reasons, despite our effort to utilize diverse search and screening strategies. First, documents only written in English were covered in the systematic map owing to finite language barriers; however, it is likely to exist in a large volume of articles in other languages, for instance in Chinese, Indian, Malaysian, and so forth. Second, publication searches were conducted in only one database, SCOPUS, and we did not carry out a citation screening because of the time limitation and for better efficiency. Third, our search string may not include all relevant literature, because the preceding systematic reviews $[22,35,37,71]$ that we referred to were typically about European agroforestry and other regions, and Asian agroforestry may have unique characters. Keywords (Tables 1 and 2) are also generated from major precedent 
studies [38,40,41,45,57-59], also significantly reflecting the characteristics of European agroforestry systems and ecosystem services.

\section{Conclusions}

The number of agroforestry-related articles in the Asia-Pacific region has been fast-growing but is still small compared to all the literature in the world. India and China are hotspots of the research field with supporting policies and institutes $[4,15,70]$ (Figure 3), whereas Western Asian countries have received little attention. Therefore, more targeted and comprehensive research is required to reduce the geographical gaps. Among the agroforestry practices, silvorable systems, especially plantation crop combinations and tree management (PC) and habitats for species/ biological control/maintenance of genetic diversity/gene-pool (HS) were the most popular. However, agrosilvopastoral and silvopastoral systems in the Asia-Pacific region have not received as much attention (Figure 4), in contrast with Europe where silvopastoral practices are predominant [35]. The linkage map expresses the occurrence of the evidence base but that does not mean that high frequency equals high or positive impacts, nor quality.

This map will contribute to designing policies, research, practical implementations, and save resources and time for decision making, by providing systematic evidence and frameworks. In particular, the heatmap offers insights to integrate ecosystem services around agroforestry systems into decision making, which is challenging [74,75]. We propose a wider range of additional studies for decision making on agroforestry works. Specifically, multiscale and upscale methods and approaches are essential to assess ecosystem services beyond biophysical approaches, in order to cover a broader range of ecosystem services including social services.

In conclusion, the systematic map identifies and describes the nature, volume, and characteristics of the research in the field of agroforestry and ecosystem services in the Asia-Pacific region. It pictures an existing evidence base on agroforestry and ecosystem service in the Asia-Pacific region. This comprehensive map could also be useful as a resource to enhance the knowledge of agroforestry-ecosystem service linkages. Furthermore, this map points out the gaps where further studies and investments should be focused.

Author Contributions: Conceptualization, M.S.P.; data coding, S.S., K.T.S., H.L., T.H.K., S.L.; writing一original draft preparation, S.S., M.S.P.; writing—review and editing, S.S., K.T.S., H.L., T.H.K., S.L., M.S.P.; supervision, M.S.P. All authors have read and agreed to the published version of the manuscript.

Funding: This work was supported by the Creative-Pioneering Researchers Program through Seoul National University (SNU).

Conflicts of Interest: The authors declare no conflict of interest. 


\section{Appendix A}

Table A1. List of search terms in English language.

\begin{tabular}{|c|c|}
\hline & Search String \\
\hline \multirow[t]{2}{*}{$\begin{array}{l}\text { Agroforestry } \\
\text { Practices }\end{array}$} & 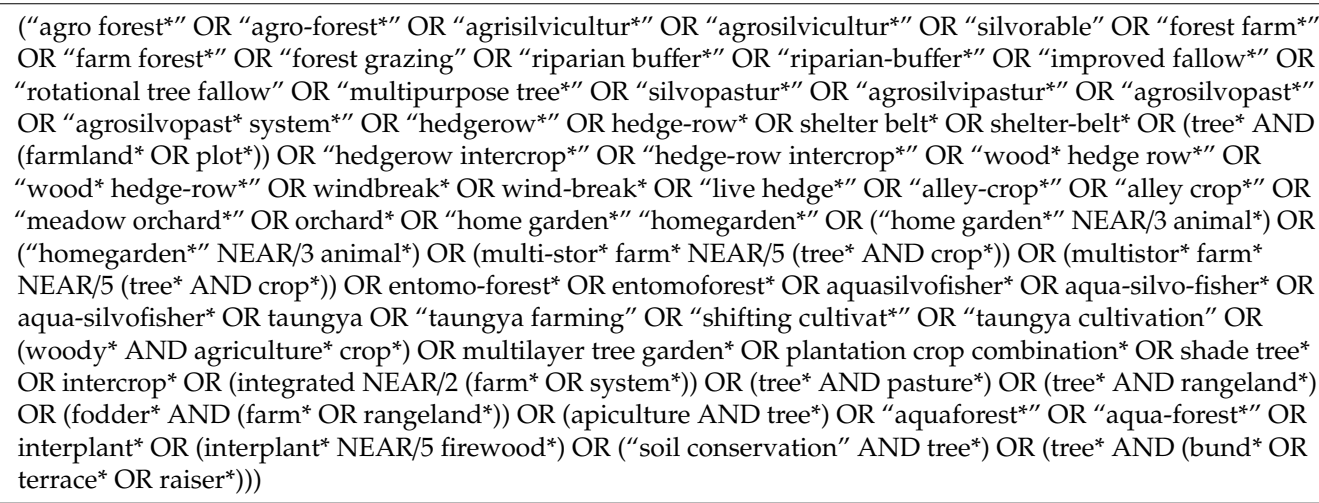 \\
\hline & AND \\
\hline \multirow[t]{2}{*}{$\begin{array}{l}\text { Ecosystem } \\
\text { Services }\end{array}$} &  \\
\hline & AND \\
\hline $\begin{array}{l}\text { Geographical } \\
\text { terms }\end{array}$ & 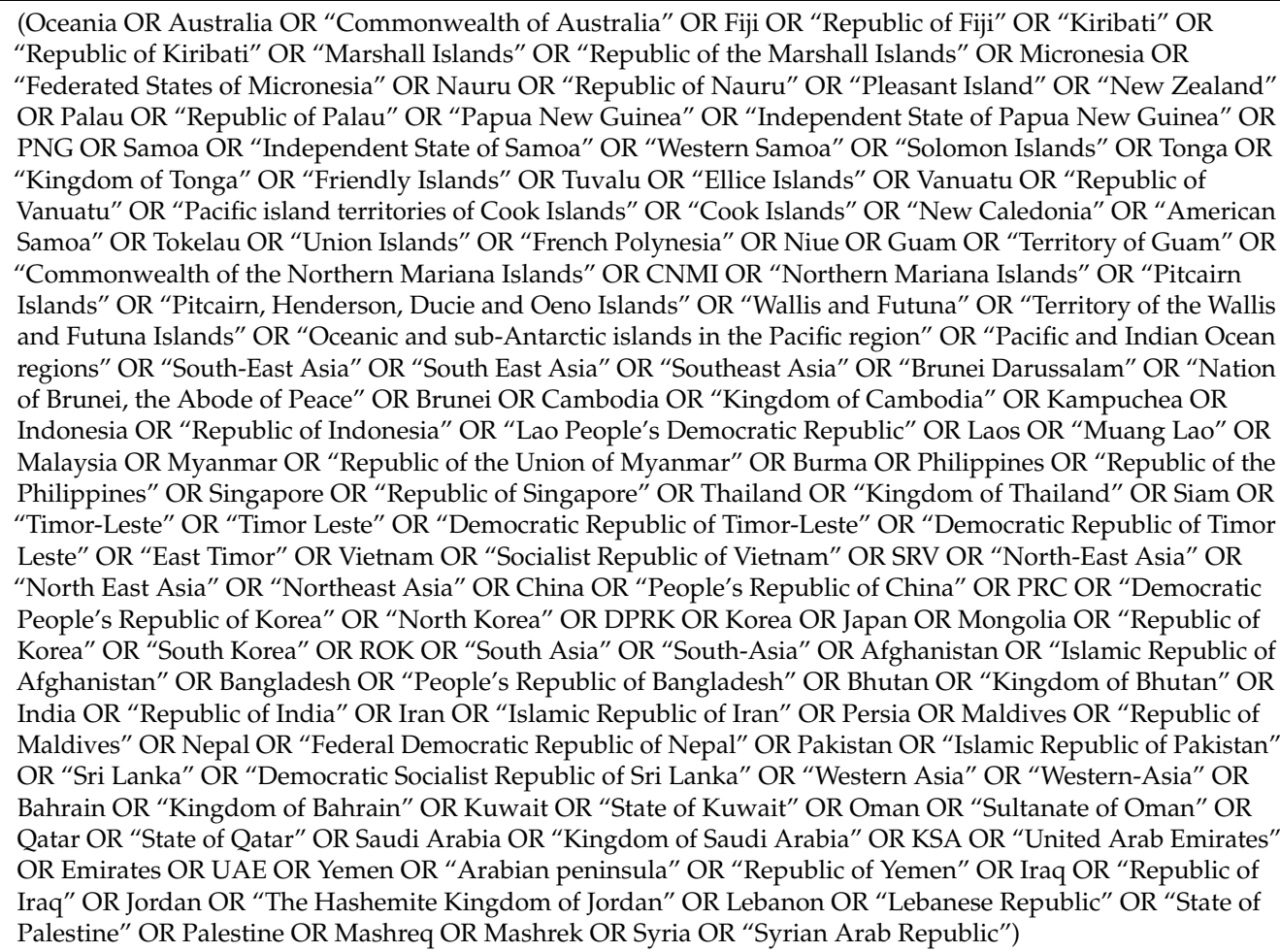 \\
\hline
\end{tabular}




\section{References}

1. World Agroforestry. What is Agroforestry? Available online: http://www.worldagroforestry.org/about/ agroforestry (accessed on 10 November 2019).

2. Zomer, R.; Trabucco, A.; Coe, R.; Place, F.; van Noordwijk, M.; Xu, J. Trees on Farms: An Update and Reanalysis of Agroforestry's Global Extent and Socio-ecological Characteristics; Working Paper 179; World Agroforestry Center: Bogor, Indonesia, 2014; pp. 1-33. [CrossRef]

3. Cannell, M.G.R. Agroforestry-A Decade of Development. ICRAF 1987, 24, 393.

4. Kumar, B.M.; Singh, A.K.; Dhyani, S.K. South Asian Agroforestry: Traditions, Transformations, and Prospects. Agroforestry -The Future of Global Land Use; Springer: Dordrecht, The Netherlands, 2012; pp. 359-389.

5. Waldron, A.; Garrity, D.; Malhi, Y.; Girardin, C.; Miller, D.C.; Seddon, N. Agroforestry Can Enhance Food Security While Meeting Other Sustainable Development Goals. Trop. Conserv. Sci. 2017, 10, 194008291772066. [CrossRef]

6. Das, T.; Das, A.K. Inventorying plant biodiversity in homegardens: A case study in Barak Valley, Assam, North East India. Curr. Sci. 2005, 89, 155-163.

7. Kumar, B.M. Land use in Kerala: Changing scenarios and shifting paradigms. J. Trop. Agric. 2005, 42, 1-12.

8. Kumar, B.M.; Takeuchi, K. Agroforestry in the Western Ghats of peninsular India and the satoyama landscapes of Japan: A comparison of two sustainable land use systems. Sustain. Sci. 2009, 4, 215-232. [CrossRef]

9. Guillerme, S.; Kumar, B.M.; Menon, A.; Hinnewinkel, C.; Maire, E.; Santhoshkumar, A.V. Impacts of public policies and farmer preferences on agroforestry practices in Kerala, India. Environ. Manag. 2011, 48, 351-364. [CrossRef]

10. Kumar, B.M. Carbon sequestration potential of tropical homegardens. J. Trop. Agric. 2006, 1, $185-204$.

11. Kumar, B.M.; Nair, P.K.R. The enigma of tropical homegardens. Agrofor. Syst. 2004, 61-62, 135-152.

12. Capistrano, A.D.; Marten, G.G. Agriculture in Southeast Asia. In Traditional Agriculture in Southeast Asia: A Human Ecology Perspective; Marten, G.G., Ed.; Westview Press: Boulder, CO, USA, 1986; pp. 6-19.

13. Matson, P.A.; Parton, W.J.; Power, A.G.; Swift, M.J. Agricultural intensification and ecosystem properties. Science 1997, 277, 504-509. [CrossRef]

14. Lobao, L.; Meyer, K. The Great Agricultural Transition: Crisis, Change, and Social Consequences of Twentieth Century US Farming. Annu. Rev. Sociol. 2001, 27, 103-124. [CrossRef]

15. De Zoysa, M. A Review of Forest Policy Trends in Sri Lanka. Policy Trend Report 2001; Institute for Global Environmental Strategies (IGES): Kanagawa, Japan, 2001.

16. Garrett, H.G.; Buck, L. Agroforestry practice and policy in the United States of America. For. Ecol. Manag. 1997, 91, 5-15. [CrossRef]

17. De Oliveira, R.E.; Carvalhaes, M.A. Agroforestry as a tool for restoration in atlantic forest: Can we find multi-purpose species? Oecologia Aust. 2016, 20, 425-435. [CrossRef]

18. Jose, S. Agroforestry for ecosystem services and environmental benefits: An overview. Agrofor. Syst. 2009, 76, 1-10. [CrossRef]

19. Chang, C.H.; Karanth, K.K.; Robbins, P. Birds and beans: Comparing avian richness and endemism in arabica and robusta agroforests in India's Western Ghats. Sci. Rep. 2018, 8, 1-9.

20. Akbar, G.; Baig, M.B.; Asif, M. Social aspects in launching successful agroforestry projects in developing countries. Sci. Vis. 2000, 5, 52-58.

21. Garrity, D.P.; Akinnifesi, F.K.; Ajayi, O.C.; Weldesemayat, S.G.; Mowo, J.G.; Kalinganire, A.; Larwanou, M.; Bayala, J. Evergreen Agriculture: A robust approach to sustainable food security in Africa. Food Secur. 2010, 2, 197-214. [CrossRef]

22. Brown, S.E.; Miller, D.C.; Ordonez, P.J.; Baylis, K. Evidence for the impacts of agroforestry on agricultural productivity, ecosystem services, and human well-being in high-income countries: A systematic map protocol. Environ. Evid. 2018, 7, 24. [CrossRef]

23. Yang, S.; Bai, J.; Zhao, C.; Lou, H.; Zhang, C.; Guan, Y.; Zhang, Y.; Wang, Z.; Yu, X. The assessment of the changes of biomass and riparian buffer width in the terminal reservoir under the impact of the South-to-North Water Diversion Project in China. Ecol. Indic. 2018, 85, 932-943. [CrossRef]

24. Tiwari, T.P.; Brook, R.M.; Wagstaff, P.; Sinclair, F.L. Effects of light environment on maize in hillside agroforestry systems of Nepal. Food Secur. 2012, 4, 103-114. [CrossRef] 
25. Bohra, B.; Sharma, N.; Saxena, S.; Sabhlok, V.; Ramakrishna, Y.B. Socio-economic impact of Biofuel Agroforestry Systems on Smallholder and Large-holder Farmers in Karnataka, India. Agrofor. Syst. 2018, 92, 759-774. [CrossRef]

26. Basu, J.P. Agroforestry, climate change mitigation and livelihood security in India. N. Zeal. J. For. Sci. 2014, 44, S11. [CrossRef]

27. Goswami, S.; Verma, K.S.; Kaushal, R. Biomass and carbon sequestration in different agroforestry systems of a Western Himalayan watershed. Biol. Agric. Hortic. 2014, 30, 88-96. [CrossRef]

28. Mupangwa, W.; Twomlow, S.; Walker, S.; Hove, L. Effect of minimum tillage and mulching on maize (Zea mays L.) yield and water content of clayey and sandy soils. Phys. Chem. Earth 2007, 32, 1127-1134. [CrossRef]

29. Hillbrand, A.; Borelli, S.; Conigliaro, M.; Olivier, E. Agroforestry for Landscape Restoration. Exploring the Potential of Agroforestry to Enhance the Sustainability and Resilience of Degraded Landscapes; FAO: Rome, Italy, 2017.

30. Jose, S.; Gillespie, A.R.; Pallardy, S.G. Interspecific interactions in temperate agroforestry. Agrofor. Syst. 2004, 61, 237-255.

31. Rivest, D.; Paquette, A.; Moreno, G.; Messier, C. A meta-analysis reveals mostly neutral influence of scattered trees on pasture yield along with some contrasted effects depending on functional groups and rainfall conditions. Agric. Ecosyst. Environ. 2013, 165, 74-79. [CrossRef]

32. Foli, S.; Reed, J.; Clendenning, J.; Petrokofsky, G.; Padoch, C.; Sunderland, T. To what extent does the presence of forests and trees contribute to food production in humid and dry forest landscapes? A systematic review protocol. Environ. Evid. 2014, 3, 15. [CrossRef]

33. Thorn, J.P.R.; Friedman, R.; Benz, D.; Willis, K.J.; Petrokofsky, G. What evidence exists for the effectiveness of on-farm conservation land management strategies for preserving ecosystem services in developing countries? A systematic map. Environ. Evid. 2016, 5, 13. [CrossRef]

34. Haddaway, N.R.; Bernes, C.; Jonsson, B.G.; Hedlund, K. The benefits of systematic mapping to evidence-based environmental management. Ambio 2016, 45, 613-620. [CrossRef]

35. Torralba, M.; Fagerholm, N.; Burgess, P.J.; Moreno, G.; Plieninger, T. Do European agroforestry systems enhance biodiversity and ecosystem services? A meta-analysis. Agric. Ecosyst. Environ. 2016, 230, 150-161. [CrossRef]

36. Miller, D.C.; Ordonez, P.J.; Baylis, K.; Rana, P. Protocol for an evidence and gap map The impacts of agroforestry on agricultural productivity, ecosystem services, and human well-being in low-and middle-income countries: An evidence and gap map. Campbell Syst. Rev. 2017, 13, 1-27. [CrossRef]

37. Santos, P.Z.F.; Crouzeilles, R.; Sansevero, J.B.B. Can agroforestry systems enhance biodiversity and ecosystem service provision in agricultural landscapes? A meta-analysis for the Brazilian Atlantic Forest. For. Ecol. Manag. 2019, 433, 140-145. [CrossRef]

38. Atangana, A.; Khasa, D.; Chang, S.; Egrande, A. Tropical Agroforestry; Springer Netherlands: Dordrecht, Netherland, 2014; ISBN 978-94-007-7723-1.

39. Nair, P.K.R. An Introduction to Agroforestry; Kluwer Academic Publishers: Dordrecht, The Netherlands, 1993; ISBN 0792321340.

40. Nair, P.K.R. Agroforestry systems in major ecological zones of the tropics and subtropics. In Proceedings of the In International Workshop on the Applications of Meteorology to Agroforestry Systems Planning and Management, Nairobi, Kenya, 9-13 February 1987; ICRAF: Nairobi, Kenya, 1989.

41. USDA Agroforestry. USDA Reports to America, Fiscal Years 2011-2012-Comprehensive Version; U.S. Department of Agriculture: Washington, DC, USA, 2013.

42. Ehrlich, P.R.; Mooney, H.A. Extinction, substitution, and ecosystem services. Bioscience 1983, 33, $248-254$. [CrossRef]

43. Daily, G.C. Nature's Services: Societal Dependence on Natural Ecosystems; Island Press: Washington, DC, USA, 1997.

44. Boyd, J.; Banzhaf, S. What are ecosystem services? The need for standardized environmental accounting units. Ecol. Econ. 2007, 63, 616-626. [CrossRef]

45. Millennium Ecosystem Assessment. Millenium Ecosystem Assessment: Ecosystems and Human Well-Being, 5th ed.; Island Press: Washington, DC, USA, 2005; ISBN 1597260401.

46. Kalaba, F.K.; Quinn, C.H.; Dougill, A.J. The role of forest provisioning ecosystem services in coping with household stresses and shocks in Miombo woodlands, Zambia. Ecosyst. Serv. 2013, 5, 143-148. [CrossRef] 
47. Maass, J.M.; Balvanera, P.; Castillo, A.; Daily, G.C.; Mooney, H.A.; Ehrlich, P.; Quesada, M.; Miranda, A.; Jaramillo, V.J.; García-Oliva, F.; et al. Ecosystem services of tropical dry forests: Insights from long-term ecological and social research on the Pacific Coast of Mexico. Ecol. Soc. A J. Integr. Sci. Resil. Sustain. 2005, 10,1-23. [CrossRef]

48. Balvanera, P.; Kremen, C.; Martínez-Ramos, M. Applying community structure analysis to ecosystem function: Examples from pollination and carbon storage. Ecol. Appl. 2005, 15, 360-375. [CrossRef]

49. Ricketts, T.H. Tropical forest fragments enhance pollinator activity in nearby coffee crops. Conserv. Biol. 2004, 18, 1262-1271. [CrossRef]

50. Maes, J.; Paracchini, M.L.; Zulian, G.; Dunbar, M.B.; Alkemade, R. Synergies and trade-offs between ecosystem service supply, biodiversity, and habitat conservation status in Europe. Biol. Conserv. 2012, 155, 1-12. [CrossRef]

51. Polasky, S.; Nelson, E.; Pennington, D.; Johnson, K.A. The impact of land-use change on ecosystem services, biodiversity and returns to landowners: A case study in the state of Minnesota. Environ. Resour. Econ. 2011, 48, 219-242. [CrossRef]

52. Karp, D.S.; Mendenhall, C.D.; Sandí, R.F.; Chaumont, N.; Ehrlich, P.R.; Hadly, E.A.; Daily, G.C. Forest bolsters bird abundance, pest control and coffee yield. Ecol. Lett. 2013, 16, 1339-1347. [CrossRef]

53. Klein, A.M.; Steffan-Dewenter, I.; Tscharntke, T. Rain forest promotes trophic interactions and diversity of trap-nesting Hymenoptera in adjacent agroforestry. J. Anim. Ecol. 2006, 75, 315-323. [CrossRef] [PubMed]

54. Logan, T.J. Agricultural best management practices for water pollution control: Current issues. Agric. Ecosyst. Environ. 1993, 46, 223-231. [CrossRef]

55. Power, A.G. Ecosystem services and agriculture: Tradeoffs and synergies. Philos. Trans. R. Soc. B Biol. Sci. 2010, 365, 2959-2971. [CrossRef] [PubMed]

56. Daily, G.C.; Matson, P.A. Ecosystem services: From theory to implementation. Proc. Natl. Acad. Sci. USA 2008, 105, 9455-9456. [CrossRef]

57. De Groot, R.S.; Alkemade, R.; Braat, L.; Hein, L.; Willemen, L. Challenges in integrating the concept of ecosystem services and values in landscape planning, management and decision making. Ecol. Complex. 2010, 7, 260-272. [CrossRef]

58. TEEB Ecosystem Services. Available online: http://www.teebweb.org/resources/ecosystem-services/\#. XC8cEKfVmH0.gmail (accessed on 12 November 2019).

59. FAO. Valuing Forest Ecosystem Services A Training Manual for Planners and Project Developers; FAO: Rome, Italy, 2019.

60. Swinton, S.M.; Lupi, F.; Robertson, G.P.; Landis, D.A. Ecosystem services from agriculture: Looking beyond the usual suspects. Am. J. Agric. Econ. 2012, 88, 1160-1166. [CrossRef]

61. O'Farrell, P.J.; Anderson, P.M.L. Sustainable multifunctional landscapes: A review to implementation. Curr. Opin. Environ. Sustain. 2010, 2, 59-65. [CrossRef]

62. Tscharntke, T.; Klein, A.M.; Kruess, A.; Steffan-Dewenter, I.; Thies, C. Landscape perspectives on agricultural intensification and biodiversity-Ecosystem service management. Ecol. Lett. 2005, 8, 857-874. [CrossRef]

63. Cannell, M.G.R.; Van Noordwijk, M.; Ong, C.K. The central agroforestry hypothesis: The trees must acquire resources that the crop would not otherwise acquire. Agrofor. Syst. 1996, 34, 27-31. [CrossRef]

64. McAdam, J.H.; Burgess, P.J.; Graves, A.R.; Rigueiro-Rodríguez, A.; Mosquera-Losada, M.R. Classifications and Functions of Agroforestry Systems in Europe. In Agroforestry in Europe: Current Status and Future Prospects; Rigueiro-Rodróguez, A., McAdam, J., Mosquera-Losada, M.R., Eds.; Springer Netherlands: Dordrecht, The Netherlands, 2009; pp. 21-41. ISBN 978-1-4020-8272-6.

65. Pullin, A.S.; Stewart, G.B. Guidelines for systematic review in conservation and environmental management. Conserv. Biol. 2006, 20, 1647-1656. [CrossRef]

66. Pullin, A.S.; Knight, T.M. Effectiveness in conservation practice: Pointers from medicine and public health. Conserv. Biol. 2001, 15, 50-54. [CrossRef]

67. Fazey, I.; Salisbury, J.G.; Lindenmayer, D.B.; Maindonald, J.; Douglas, R. Can methods applied in medicine be used to summarize and disseminate conservation research? Environ. Conserv. 2004, 31, 190-198. [CrossRef]

68. Stewart, L.A.; Tierney, J.F. To IPD or not to IPD? Eval. Health Prof. 2002, 25, 76-97. [CrossRef] [PubMed]

69. Moher, D.; Liberati, A.; Tetzlaff, J.; Altman, D.G. Preferred reporting items for systematic reviews and meta-analyses: The PRISMA statement. Ann. Intern. Med. 2009, 154, 264-269. [CrossRef] 
70. Reidsma, P.; Feng, S.; van Loon, M.; Luo, X.; Kang, C.; Lubbers, M.; Kanellopoulos, A.; Wolf, J.; Van Ittersum, M.K.; Qu, F. Integrated assessment of agricultural land use policies on nutrient pollution and sustainable development in Taihu Basin, China. Environ. Sci. Policy 2012, 18, 66-76. [CrossRef]

71. Cheng, S.H.; MacLeod, K.; Ahlroth, S.; Onder, S.; Perge, E.; Shyamsundar, P.; Rana, P.; Garside, R.; Kristjanson, P.; McKinnon, M.C.; et al. A systematic map of evidence on the contribution of forests to poverty alleviation. Environ. Evid. 2019, 8, 3. [CrossRef]

72. Arts, B.; Appelstrand, M.; Kleinschmit, D.; Pülzl, H.; Vissen-Hamakers, I.; Eba'a Atyi, R.; Enters, T.; Mcginley, K.; Yasmi, Y. Discources, actors and instruments in international forest governance. Embrac. Complex. Meet. Chall. Int. For. Gov. 2010, 28, 57-73.

73. Zhouri, A. Global-Local Amazon Politics: Conflicting Paradigms in the Rainforest Campaign. Theory Cult. Soc. 2004, 21, 69-89. [CrossRef]

74. Maes, J.; Egoh, B.; Willemen, L.; Liquete, C.; Vihervaara, P.; Schägner, J.P.; Grizzetti, B.; Drakou, E.G.; La Notte, A.; Zulian, G.; et al. Mapping ecosystem services for policy support and decision making in the European Union. Ecosyst. Serv. 2012, 1, 31-39. [CrossRef]

75. Nieto-Romero, M.; Oteros-Rozas, E.; González, J.A.; Martín-López, B. Exploring the knowledge landscape of ecosystem services assessments in Mediterranean agroecosystems: Insights for future research. Environ. Sci. Policy 2014, 37, 121-133. [CrossRef]

(C) 2020 by the authors. Licensee MDPI, Basel, Switzerland. This article is an open access article distributed under the terms and conditions of the Creative Commons Attribution (CC BY) license (http://creativecommons.org/licenses/by/4.0/). 